| Araştırma Makalesi / Research Article |

\title{
Türkiye'de Yürütülen Dijital Oyun Bağımlılığı Çalışmalarındaki Yöntem ve Sonuçların Sistematik Incelemesi
}

\section{Systematic Review of Method and Results of Digital Game Addiction Studies Conducted in Turkey}

\section{Esra Şimşek ${ }^{1}$, Türkan Karakuş Yılmaz ${ }^{2}$}

Anahtar Kelimeler
oyun bağımlıı̆̆ı
dijital oyun bağımlılı̆ı
çevrimiçi oyun
bağımlıığı
bilgisayar oyunu
bağımlılığı
internette oyun oynama
bozukluğu
sistematik inceleme
metodoloji
değişken

Keywords
game addiction
digital game addiction
online game addiction
computer game
addiction
internet game playing
disorder
systematic review
methodology
variable

Başvuru Tarihi/Received 13.09.2019

Kabul Tarihi /Accepted 18.06.2020

\section{Öz}

Bu çalışmanın amacı, Türkiye'de 2010-2018 yılları arasında dijital oyun bağımlılı̆̆ üzerine yapılan çalışmalardaki metodolojik eğilimleri ve elde edilen bulguları kapsamlı ve bütüncül bir şekilde incelemek ve dijital oyun bağımlılı̆̆ ile ilişkili faktörleri belirlemektir. Bu amaç doğrultusunda konuyla ilgili lisansüstü tezler ve çevrimiçi makaleler taranarak bir sistematik inceleme yürütülmüştür. Dijital oyun bağımlılığı ile ilişkili anahtar kelimelerle Google Akademik, Web of Science, YÖK Tez Kataloğu, ULAKBIM ve ERIC veri tabanları araştırılmış, dijital oyun bağımlılığına etki eden faktörleri ele alan, ampirik, tam metne erişimi olan 26 çalışma analize dahil edilmiştir. İnceleme sonucunda metodolojik olarak özellikle örneklem seçimi, veri toplama süreci ve sınırlılıkların ifade edilmesi konusunda eksiklikler olduğu görülmüştür. Bulgular incelendiğinde çalışmalarda genellikle demografik değişkenlerin dijital oyun bağımlığına olan etkilerine bakıldığı bunlar arasında cinsiyet, yaş, anne baba eğitim düzeyinin gözle görülür etkileri olduğu saptanmıştır. Öte yandan psiko-sosyal değişkenler ve dijital oyunlara özgü değişkenler çok az çalışmada ele alınmıştır. Çalışmada ele alınan unsurların derinlemesine incelenmesinin daha nitelikli, daha orijinal ve metodu güçlü dijital oyun bağımlılığı çalışmaları geliştirebilmek için araştırmacılara bir yol haritası sunacağı düşünülmektedir.

\section{Abstract}

The aim of this study was to determine the methodological trends and findings in a comprehensive and integrated manner and to examine factors associated with the digital game addiction studies on digital gaming addiction in Turkey between the years of 2010-2018. For this purpose, a systematic review was conducted by screening postgraduate theses and research articles. Google Academic, Web of Science, YÖK Thesis Catalog, ULAKBIM and ERIC databases have been searched with keywords related to digital game addiction, and 26 studies which are empirical, full text accessible are included in the analysis. As a result of the analysis, it was observed that there were deficiencies in terms of sample selection, data collection process and expressing the limitations. When the findings were examined, it was determined that the effects of demographic variables on digital game addiction were found to have visible effects, including gender, age, and parental education level. On the other hand, psychosocial variables and variables specific to digital games have been handled in very few studies. It is thought that the in-depth examination of the elements discussed in the study will provide researchers with a roadmap to develop more qualified, more original and method-based digital game addiction studies.

\footnotetext{
${ }^{1}$ Sorumlu Yazar, Atatürk Üniversitesi, Eğitim Fakültesi, Bilgisayar ve Öğretim Teknolojileri Eğitimi, Erzurum, TÜRKiYE; https://orcid.org/0000-0003-0859-2787
} ${ }^{2}$ Atatürk Üniversitesi, Eğitim Fakültesi, Bilgisayar ve Öğretim Teknolojileri Eğitimi, Erzurum, TÜRKiYE; https://orcid.org/0000-0002-5809-3962 
Extended Abstract

\section{Introduction}

Computer games take individuals away from real life and offer them a magical and virtual environment (Yüksel, 2006). The fact that children can do many things in the virtual world that they cannot do in real life creates a relaxation effect in children. Relaxing children become accustomed to these channels and even become addicted in time. The increase in the number of digital games and users has led researchers to focus on the effects of games on people. There are many studies about digital game addiction and mostly similar variables are interpreted by descriptive analysis methods (Aslan, 2016; Gündüz, 2015). Correlational analyzes in addiction studies often present intimidating figures and can be misleading (Carnagey \& Anderson, 2004). There are also many studies on the effects of severe video game exposure and variables related to aggression, since it is also assumed to be related (Carnagey \& Anderson, 2004). However, considering the factors of similar variables in digital game addiction studies makes the literature saturated. In such studies, generally similar variables are repeatedly tested in different groups. This requires a new route for addiction studies. It is thought that the information obtained in the study will provide a road map to the future researchers in order to put forward original research ideas for addiction studies. In this study, it is aimed to reveal the methodological tendencies and addiction related factors in the studies of digital game addiction in a comprehensive and holistic way.

\section{Method}

In this study, it is aimed to review the methodological trends and the factors that affect addiction and in digital game addiction studies. In order to achieve this purpose, a systematic review, which is one of the qualitative research methods, was conducted in the study. Since 2010, direct digital gaming addiction has been carried out in Turkey has reached 221 publications related issues. Since this study focuses on variables related to digital game addiction, 26 publications in which predictive or correlational analyzes have been conducted have led to the findings of this study.

\section{Result and Discussion}

In the findings obtained from the study, methodological tendencies are general information about thesis and articles, according to data collection tools, analysis types and limitations; and related factors were examined according to 29 variables. Many different sampling types have been used, and the number of participants in the studies varies between 150 and 1000 . Since most of the studies were via surveys, large samples were studied. However, the scarcity of expected or cluster sampling methods on a sensitive subject such as addiction draws attention. Moreover, in a significant part of the studies, the sample type was not specified. Primary, secondary and high school students were selected as the sample at most, so most of the studies collected data from schools. Qualitative studies were also included in the study, but no qualitative study that met the article selection criteria and revealed the causes of addiction was not found. The scales that are usually available in the studies have been used and in some studies they have been developed or adapted by the researchers. While the existing scales were also used for the factors affecting the studies, in the majority of the studies, personal information forms were used. A total of 33 different variables were included in the studies. In general, it is observed that men are prone to addiction in terms of gender, and the addiction increases as the education level of the parents, socioeconomic level, possession of digital tools and opportunities and the level of playing games increase. Although addiction increases as the grade level increases, the results obtained in studies dealing with age are the opposite. While factors such as academic success, sports, emotional balance level are inversely related to addiction, psychosocial factors such as loneliness, alienation, being a night person, neurotic disorder are in direct proportion.

When the literature on digital game addiction is examined, it is seen that the researches are generally limited to the studies using similar variables. Although direct statistical analysis with the data obtained with Likert type scales reveals a significant relationship between independent variables and game addiction, it does not reveal the level of actual addiction. It is seen that factors related to certain methodological trends are used in digital game addiction studies, limited sample selection procedures are used, variables based on theoretical foundations are not determined. The use of non-theory based variables, such as the frequency of game purchases and the frequency of playing games, which are strictly linked to game addiction reveals the need for methodological strengthening in studies. In addition, it is predicted that working on variables that include current dynamics and which can be manipulated will provide more added value in digital game addiction literature rather than saturated variables. 
GíRiş

Çağımızın en vazgeçilmez teknolojisi olan İnternet her yaş grubunun ihtiyaçlarına hitap etmekle birlikte, özellikle çocuk ve ergenlerin sürekli ilgisini çekmekte ve İnterneti aktif olarak kullanmalarını sağlamaktadır. Neredeyse 1 yaşından itibaren İnternet ile tanışan çocuklara, bu ortam pek çok aktivite imkânı sunmaktadır (Aslan, 2016). Son 20 yılda geleneksel, gerçek ve sosyal oyunların dünyası olan sokaktan uzaklaşan kentli çocuklar, bilgisayar ve İnternet'in zenginleştirerek büyüttüğü dijital oyun dünyasında kendilerine yer bulmaktadırlar (Horzum, 2011). Çevrimiçi veya çevrimdışı bilgisayar veya diğer elektronik cihazların yardımıyla oynanan oyunlar olarak tanımlanan dijital oyunlar (Martinez-Garza, Clark, Killingsworth, \& Adams, 2016), giderek daha gerçekçi grafik ve senaryolara kavuşmakta ve her yaştan bireylerin ilgisini çekmektedir. Yapılan araştırmalar, kontrollü bir şekilde oynanan dijital oyunların el-göz koordinasyonunu sağlama, hayal gücünü artırma, uzamsal becerileri geliştirme gibi birçok olumlu yanları olduğunu göstermektedir (Irmak \& Erdoğan, 2016). Öte yandan özellikle şiddet içerikli oyunların negatif etkileriyle birlikte, agresiflik, sosyal izolasyon ve bağımlılık gibi bir takım olumsuz çıktılar da dijital oyun literatüründe sıklıkla ele alınmaktadır (Ferguson, 2007; Greitemeyer, 2018). Dijital oyun bağımlılığı (digital game addiction) bilgisayar ve video oyunlarının aşırı kullanımı sonucu kontrol edilememesi ile duygusal ve sosyal problemlere sebep olması olarak tanımlanmaktadır (Lemmens, Valkenburg, \& Peter, 2009). Weinstein (2010) ise dijital oyun bağımlılığını, günlük yaşamımızı olumsuz yönde etkileyen çokça ve zorlayan dijital oyun kullanımı olarak tanımlamıştır. Oyun bağımlılığı kavramı ayrıca oyunların aşırı kullanımı, obsesif-kompulsif oyun oynama, problemli oyun oynama davranışları, patolojik oyun oynama davranışları gibi farklı terimlerle de ifade edilmektedir (Irmak \& Erdoğan, 2016). Yani kısacası bağımlılık, oyunun çok fazla oynanması ile değil, sonucunda oluşturduğu negatif durumlarla belirlenmektedir. Bu nedenle bağımlılığın ölçülmesinde bu negatifliğin ele alınması gerekmektedir.

Oyun literatüründe özellikle şiddet içeren oyunların etkileri ile oyun bağımlılığı konusunda pek çok çalışma bulunmaktadır (Anderson, Carnagey, Flanagan, Benjamin, Eubanks \& Valentine, 2004; Weber, Ritterfeld \& Kostygina, 2006). Bu çalışmaların önemli bir kısmında bu oyunların psikososyal ve davranışsal etkileri ele alınmaktadır (Kuss \& Griffiths, 2012). Bulgular çalışmalara göre değişmekle birlikte, şiddet içeren bilgisayar oyunlarının genel olarak yalnızlık, saldırgan davranışlar, anksiyete bozukluğu, düşük yaşam doyumu, depresyon, şiddete karşı duyarsızlaşma, dikkat sorunları gibi psikososyal sorunlar ile ilişkili olduğu ifade edilmektedir (Irmak \& Erdoğan, 2016). Dijital oyun bağımlılığının biyolojik olarak psikomotor beceri bozukluğu, hiperaktivite, baş ağrısı, göz bozuklukları gibi etkilerden bahsedilirken, psikolojik olarak ise agresif ve anti-sosyal davranışlar gösterme, şiddet eğilimi, gerçek hayattan kaçınma ve sıkılma, gerçek ve hayal arasında karmaşa yaşama gibi etkileri olduğu vurgulanmaktadır (Horzum, 2011). Dijital oyun bağımlılı̆ı hem bilimsel araştırmalarda hem de medyada yer alan haberlerde sık sık ele alınmakta ve özellikle çocukların internet ve bilgisayar oyunları ile her geçen gün daha çok vakit geçirdikleri ortaya çıkmaktadır (Ilgaz, 2015). Bilhassa, son yıllarda oyun bağımlıı̆̆ı konusunda psikiyatri kliniklerine başvuru sayılarındaki artış, ailelerin destek talebinde bulunması ve araştırmacıların ortaya çıkardıkları kanıtlar endişeleri artırmaktadır (Griffiths \& Meredith, 2009).

Dijital oyun bağımlılı̆ı her geçen gün daha da ciddi bir sorun haline geldiğinden bu konudaki çalışmalar da günden güne artmakta, bağımlıı̆̆ anlamak, nedenlerini ve sonuçlarını ortaya koymak için çalışmalar yapılmaktadır (Bhagat, Jeong, \& Kim, 2020). Türkiye'de yürütülen dijital oyun bağımlılığı çalışmaları 2010 yılından bu yana büyük bir artış göstermiştir; 2010-2018 yılları arasında yapılan çalışma sayısı 2010 yılına kadar yapılanlardan 5 kat daha fazladır (Scholar Google, 2020; Web of Science, 2020). Yapılan çalışmalara bakıldığında dijital oyun bağımlılığının nedenlerini anlamak için yapılan çalışmalarda çoğunlukla dijital oyun bağımlılı̆̆ ile ilişkili faktörler (değişkenler) kestirimsel analiz yöntemleriyle yorumlanmaktadır (Aslan, 2016; Gündüz, 2015). Demografik özellikler, oyun oynama alışkanlıkları ve oynanan oyunların özellikleri gibi sıklıkla ele alınan faktörlerle ilişkisel olarak yapılan çalışmalar literatürü doygun hale getirmektedir. Ayrıca dijital oyun bağımlıı̆̆ı çalışmalarında belirli bir bağımlılık düzeyi temel alınmadan, çoğunlukla ilişkisel analizlerle sonuçlar elde edildiğinden ele alınan değişkenler genellikle göz korkutucu bir şekilde bağımlııkla ilişkili bulunmaktadır. Örneğin 644 ortaokul öğrencisi ile yapılan bir çalışmada oyun bağımlılık skorları oyun oynama süresi, yaşam doyumu, yalnızlık, sosyallik ve agresiflik gibi unsurlarla anlamlı derecede ilişkiliyken, aynı grupta bağımlılık kriterlerini karşılayan öğrenci oranının sadece \%2 olduğu görülmüştür (Lemmens ve diğ., 2009). Çalışmada ilgili örneklem için değişkenlerin tam olarak dijital oyun bağımlılığından kaynaklı olarak değişiklik gösterip göstermediği soru işaretidir. Dolayısı ile bağımlılık çalışmalarında ilgili değişkenlerin teorik olarak gerçekten bağımlılıkla ilişkili olup olmadığı, metodolojik olarak ölçüm ve analizlerin bu ilişkiyi ortaya koymada yeterli olup olmadığını anlamak gerekmektedir. Bağımlılık çalışmaları için yeni rotaların oluşturulması, teorik alt yapısı oluşturulmak suretiyle yeni faktörlerin incelenmesi ve bağımlılı̆̆ daha iyi anlamayı sağlayacak metotların geliştirilmesi bir ihtiyaç haline gelmektedir. İyi bir çalışmada metodun açık olması, örneklemin, veri toplama sürecinin iyi açıklanması gerekmektedir (Kim, Sefcik, \& Bradway, 2017; López, Valenzuela, Nussbaum, \& Tsai, 2015). Ancak pek çok çalışmada metodolojinin yeterince açıklanmadı̆̆ı, ampirik çalışmalarda istatistiksel olarak anlamlı olan sonuçlarda etki büyüklüğünün çok az çalışmada ifade edildiği (Henson, Hull, \& Williams, 2010), çoğu çalışmanın ele alınan değişkenler için uygun teorik bir altyapı oluşturmadığı (Kim ve diğ., 2017) ifade edilmektedir. Ayrıca, bu tür çalışmalarda gerek örneklem seçimi gerekse veri toplama süreci ile ilgili sınırılıklar bulunmasına ve gelecek çalışmalar için önemli ipuçları sağlamasına rağmen çoğu çalışmada bu tür sınırlılıklar genellikle ifade edilmemektedir. Oysa dijital oyun bağımlılığı çalışmalarında metodolojinin iyi geliştirilmiş ve açıklanmış olması önemlidir.

Bağımlılı̆̆ın nedenleri için yapılan çalışmalarda oyuncunun kişisel özellikleri önemli bir faktör olsa da (Kim, Namkoong, Ku, \& Kim, 2008), dijital oyunların sahip olduğu bazı özellikler ve bireyde yaşattığı duygular da oyuncuda bağımlılık faktörünü artıran unsurlar olarak ele alınmaktadır. Oyunda sosyal etkileşimin yoğun olması, sürekli başarı elde edilmesi ve yine oyuncunun oyun dünyasının gerçekten içindeymiş gibi hissetmesi anlamına gelen kaptırma (immersion) hissinin yaşanması da bağımlılıkla ilişkili 
değişkenlerdir (Kneer \& Glock, 2013). Oyuncunun tamamen kendini oyuna kaptırarak oyun oynarken geçen zamanı ya da etrafında olup bitenlerin farkında olmaması anlamına gelen akış hissi de oyun bağımılıı̆ı için bir faktör olarak ele alınmaktadır (Chou \& Ting, 2003). Akış deneyimi ise sınırlı ya da sınırsız öyküye sahip olması, basit ya da karmaşık yapıda olması, tek ya da çok oyunculu olması, gibi pek çok unsur ile farklılaşabilmektedir (İnal \& Çağıltay, 2005). Çevrimiçi, çok oyunculu, sınırsız öyküye sahip oyunların daha fazla bağımlılık oluşturabileceği ifade edilmektedir (Kuss, Louws, \& Wiers, 2012; Lemmens \& Hendriks, 2016). Bağımlılık çalışmalarında cinsiyet, yaş, medeni durum, sosyoekonomik durum ya da eğitim seviyesi gibi demografik özellikler ile, oyun oynama süresi, oynanan oyun türü, oyunların sevilen özellikleri gibi unsurlar sıklıkla ele alınan değişkenlerdir (Griffiths, Davies, \& Chappell, 2004). Türkiye'de yürütülen çalışmalarda genellikle cinsiyet, sosyoekonomik durum, oyunun oynandığı bağlam genellikle oyun bağımlıı̆̆ ile ilişkili bulunmaktadır (Altun \& Atasoy, 2018; Toker \& Baturay, 2016). Ancak bu konuda yüzlerce farklı değişken ele alınmış olup pek çok farklı sonuçlar elde edilmiştir. Bu nedenle bağımlılığın doğasını daha iyi anlamak, incelenebilecek farklı değişkenler için alt yapı oluşturmak ve böylece bağımlılı̆a ilişkin çözüm önerilerini artırmak için mevcut literatürün kapsamlı bir analizini yapmak gerekmektedir.

Bu çalışma ile dijital oyun bağımlılığı çalışmalarındaki metodolojik eğilimleri, ele alınan değişkenleri ve bu değişkenlerin elde edilen sonuçlar üzerindeki etkilerinin tartışılması amaçlanmıştır. İncelemenin özellikle bu alanda çalışma yapacak araştırmacılar için metodolojide dikkat etmeleri gereken unsurlar ile dijital oyun bağımlıı̆ı̆ ile ilişkili ele alınabilecek faktörler konusunda öneriler getirmesi beklenmektedir. Çalışmanın amacı doğrultusunda aşağıdaki araştırma sorularına cevap aranmıştır.

2010- 2018 yılları arasında Türkiye'de yürütülmüş, dijital oyun bağımlılığına neden olan değişkenlerin ele alındığı çalışmalarda;

1. Dijital oyun bağımlılığı çalışmalarındaki metodolojik eğilimler nelerdir?

a. Çalışmalardaki örneklem özellikleri nelerdir?

b. Çalışmalardaki veri toplama araçları nelerdir?

c. Çalışmalardaki veri analiz yöntemleri nelerdir?

d. Çalışmalarda ifade edilen sınırlılıklar nelerdir?

2. Dijital oyun bağımlılığı çalışmalarının sonuçları nelerdir?

a. Etkisi bulunan ve bulunmayan değişkenler çalışmalara göre nasıl bir dağılım göstermiştir?

b. Etkisi bulunan değişkenlerin hangi boyutları için dijital oyun bağımlılığı düzeyleri farklılaşmaktadır?

Araştırma sorularının cevaplandırılması amacıyla, dijital oyun bağımlılı̆ı ile ilgili lisansüstü tezler ve çeşitli veri tabanlarında tam metne erişilebilen makaleler ile bir sistematik inceleme gerçekleştirilmiştir.

\section{YÖNTEM}

Bu bölümde çalışmanın araştırma deseni, veri toplama süreci, verilerin analizi, geçerlik ve güvenirlik konularına ilişkin bilgiler yer almaktadır.

\section{Araştırma Deseni}

Bu araştırmada, dijital oyun bağımlılığı çalışmalarındaki metodolojik eğilimlerin bağımlılığa etki eden değişkenlerin belirlenmesi amacıyla nitel araştırma yöntemlerinden sistematik inceleme yöntemi kullanılmıştır. Sistematik inceleme mevcut çalışmaları tespit eden, içeriğini seçen ve değerlendiren, verileri analiz eden ve sentezleyen ve kanıtları, bilinenler ve bilinmeyenler hakkında anlamlı ve net sonuçlara varılabilecek şekilde rapor eden bir metodolojidir (Denyer \& Tranfield, 2009). Sistematik inceleme geleneksel anlamda bir literatür incelemesi olarak değil, kendi başına, genellikle teoride ya da uygulamada bulunan bir problemden yola çıkan, mevcut çalışmaları kullanarak, açıkça belirlenmiş bir soruyu araştıran bağımsız bir araştırma çalışmasıdır (Denyer \& Tranfield, 2009). Sistematik inceleme ilgili çalışmaları tanımlamak, eleştirel biçimde değerlendirmek ve bulguları tutarlı biçimde sentezlemek gibi üç temel aracı içerir (Gough, Oliver, \& Thomas, 2012). Bu çalışmada amaç sadece bir içerik analizi yapmak olmayıp, dijital oyun bağımlılığı çalışmalarında yer alan unsurların incelenerek bu tür çalışmalarda hangi faktörlerin etkili olabileceğinin ortaya konulması ve dolayısı ile bu alanda çalışacak araştırmacılar için de bir yol haritası sunması amaçlanmıştır.

\section{Veri Toplama Süreci}

Sistematik incelemenin hangi adımları içermesi gerektiği farklı çalışmalarla ortaya koyulmuştur. (Khan, Kunz, Kleijnen, \& Antes, 2003) tarafından önerilen 5 adımlı inceleme ile bu çalışma takip edilmiştir. Çalışmaların araştırılması sürecinde öncelikle bazı oyun bağımlılı̆ı çalışmaları incelenerek genellikle kullanılan anahtar kelimeler belirlenmiştir. Bu aramalarla elde edilen çalışmalar iki aşamada incelenerek seçilmiştir. Illk aşamada konu başlığı ve özet kısmı, ikinci aşamada ise daha detaylı olarak yöntem ve sonuç kısmı incelenmiştir. illk incelemelerde 221 çalışma belirlenmiştir. Ancak bu çalışmalar arasında ölçek geliştirme ve bağımlılığın etkilerini inceleyen çalışmalar elendiğinde 37 adet çalışma elde edilmiştir. Bu çalışmaların ise özellikle yöntem bölümü incelenmiş, kestirimsel analiz yapılan (sadece betimsel olmayan) ve sonuç kısımlarında yeterli bilgi sunan 26 çalışma analize dahil edilmiştir. Takip edilen 5 adım ve çalışmada uygun makalelerin seçim prosedürleri Tablo 1'de görülmektedir. 
Tablo 1. Sistematik inceleme adımları ve uygun makalelerin seçim prosedürleri

Sistematik inceleme adımları

Incelenecek çalışmalar için

kriterlerin belirlenmes

Uygun çalışmaların

belirlenmesi

Çalışmaların kalitesinin

belirlenmesi

Incelemenin özetlenmesi

Bulguların yorumlanması
Çalışmada yürütülen prosedürler

Web of Science, Google Akademik, YÖK Tez Kataloğu, ULAKBiM, ERIC veri tabanlarından erişilen makaleler ve tezler

2010-2018 yılları arasında yapılan, "oyun bağımlılı̆ı” (n=1453), "dijital oyun bağımlılı̆ı" (n=321), "çevrimiçi oyun bağımlılığı” (n=283), "bilgisayar oyunu bağımlılığı” ( $n=163)$, “internette oyun oynama bozukluğu” ( $n=62)$

(İngilizce ve Türkçe) anahtar kelimeleri ile ulaşılan çalışmalar.

Türkiye'de yürütülmüş çalışmalar ( $n=221)$

Erişime açık, tam metin, ampirik yani veriye dayalı çalışmalar ( $n=85)$

"Bağımlılığa etki eden" veya "bağımlılıkla ilişkili değişkenler"i inceleyen çalışmalar (n=37)

Makale analizi için belirlenen başlıklara yeterli cevap bulunabilen çalışmalar $(n=26)$

Çalışmalar uzman görüşü alınarak oluşturulan bir analiz dosyasında analiz edilmiş ve elde edilen frekanslar bulgularda sunulmuştur

Uzman görüşü alınarak ve literatür ile destekleyerek bulgular yorumlanmıştır

Araştırma kapsamında çalışmalara ilişkin tarama sonucunda YÖK ulusal tez merkezinde 8 yüksek lisans tezi ile yukarıda bahsi geçen veri tabanlarından 18 makale olmak üzere toplam 26 yayına ulaşılmıştır. Ancak çalışmanın kapsamı, çalışmanın hazırlandığı 2018 yılı Aralık ayından bu yana yapılan çalışmalar ile sınırıdır.

\section{Verilerin Analizi}

Sistematik analiz çalışmalarında çalışmanın amacına göre çalışmanın künyesi ile ilgili bilgiler, çalışmanın amacı, örneklemi, veri toplama ve analiz yöntemleri gibi metodolojik unsurlar, ele alınan kavramlar, elde edilen çıtılar ile sistematik inceleme amacına uygun temel bulgular analiz edilmelidir (Peters ve diğ., 2015). Bu çalışmanın amacı özellikle bağımlılık çalışmalarında metodu ve sonuçları anlamak olduğundan bu doğrultuda bir analiz yapılmıştır. Analizler çevrimiçi bir Excel dosyası üzerinde çalışmanın künyesi (referans, yazarlar, yıl vb.), metodolojik unsurlar (örneklem sayısı, örneklem yaş grubu, örneklem seçim prosedürü, veri toplama araçları, kimler tarafından geliştirildiği, veri toplama prosedürü, veri analiz yöntemi, çalışmada ifade edilen sınırlılıklar) ve bulgular (yöntemde ve bulgularda ifade edilen değişkenler, etkisi bulunan ve bulunmayan değişkenler, etkisi bulunan değişkenlerde hangi boyutların etkili olduğu, ve çalışmanın önerileri) şeklinde toplam 29 başık altında analiz edilmiştir. Analiz işlemleri tamamlandıktan sonra bulgular dijital oyun bağımlılığı çalışmalarındaki metodolojik eğilimler ve dijital oyun bağımlılığına ilişkin araştırma sorularına göre sunulmuştur.

\section{Geçerlik ve Güvenirlik}

Nitel araştırmalarda geçerlilik ve güvenilirlik için inandırıcılık, araştırmacının yetkinliği ve sonuçların doğruluğu gibi kavramlardan bahsetmek mümkündür (Krefting, 1991). Bunlara ek olarak aktarılabilirlik, tutarlılık ve teyit edilebilirlik de nitel çalışmalarda geçerlilik ve güvenilirlik için önemli unsurlardır (Guba \& Lincoln, 1994). Bu çalışmada geçerlik ve güvenirliği sağlamak için; uzman görüşü, akran değerlendirmesi, derinlemesine veri toplama, veri toplama ve analiz sürecinin detaylı ve açık bir şekilde sunulması gibi bazı stratejiler kullanılmıştır (Yıldırım \& Şimşek, 2011). Aşağıda Tablo 2'de geçerlilik ve güvenilirlik unsurları için çalışmada yürütülen prosedürler ele alınmıştır.

Tablo 2. Çalışmanın geçerlilik ve güvenilirlik adımları

Geçerlilik \& Güvenilirlik Kullanılabilecek yöntemler

unsuru (Yıldırım \& Şimşek, 2011)

Çalışmada yürütülen adımlar

Uzun süreli etkileşim

İnandırıcılık (sonuçların doğruluğu)

Derin odaklı veri toplama Çeşitleme

Uzman incelemesi Katılımcı teyidi

Aktarılabilirlik

Ayrıntılı betimleme Amaçlı örnekleme

Tutarlılık

Tutarlılık incelemesi

Teyit edilebilirlik

Teyit incelemesi
Sistematik analiz literatür taramasına dayalı bir araştırma olduğundan elde edilen uzman incelemesi, araştırmacı çeşitlemesi yapılmıştır.

Verilere ulaşma şekli, kullanılan anahtar kelimeler, analize dahil edilecek makalelerin seçim prosedürü, incelenen makalelerle ilgili pek çok ayrıntı açıkça belirtilmiştir. Ayrıca makale yazım aşamasının sonuna kadar sürekli literatür taraması yapılarak bilgilerin güncelliği kontrol edilmiştir.

Uzman ve akran görüşleri ile elde edilen kategoriler, bulguların kategorilerle ilişkili olup olmadığı incelenmiştir.

Aktarılabilirlikle ilgili verilen yöntemler teyit edilebilirlik için de geçerlidir, ayrıca veri analiz süreci ayrıntılı şekilde açıklanmıştır.

Incelenen çalışmalarda kodlamalar sonucu temaların tarafsız ve açık olmasına dikkat edilmiş ve dijital oyun alanında 14 yıllık deneyime sahip uzmandan görüşler alınmıştır. 


\section{BULGULAR}

Bu bölümde, betimsel olarak analiz edilen dijital oyun bağımlılığı çalışmalarındaki metodolojik eğilimler ve bu çalışmaların sonuçları sunulmuştur.

\section{Dijital Oyun Bağımlılığı Çalışmalarındaki Metodolojik Eğilimler}

Tablo 3'te görüldüğü gibi çalışma için toplanan 8 yüksek lisans tezi ve 18 makale olmak üzere toplam 26 yayının başlığı, yayın türü, örneklem türü, grubu ve boyutu, anlamlı etki bulunan değişkenler ve etkisi bulunmayan değişkenler adı altında tablolaştırılmıştır. Ayrıca yayın başlığı sütununda verilen atıflara ait çalışmaların kaynakçası Ek-1'de “Analiz Edilen Çalışmalar İçin Kaynakça" başlığı altında incelenebilir.

Tablo 3. Yayınlanan tez ve makalelerdeki örneklem ve bulgulara yönelik analizler

\begin{tabular}{|c|c|c|c|c|c|c|c|}
\hline No & Yayın başlığı & $\begin{array}{l}\text { Yayın } \\
\text { türü }\end{array}$ & $\begin{array}{l}\text { Örneklem } \\
\text { türü }\end{array}$ & Örneklem grubu & $\begin{array}{l}\text { Örneklem } \\
\text { boyutu }\end{array}$ & Anlamlı etkisi bulunan değişkenler & $\begin{array}{l}\text { Etkisi bulunmayan } \\
\text { değişkenler }\end{array}$ \\
\hline 1 & Horzum (2011) & Makale & Belirtilmemiş & $\begin{array}{l}\text { İlkokul ve Ortaokul } \\
(3,4 \text { ve } 5 \text {. sınıf })\end{array}$ & $\begin{array}{l}889 \text { Katılımcı } \\
(\mathrm{K}: 444 \mathrm{E}: 445)\end{array}$ & $\begin{array}{l}{ }^{*} \text { Cinsiyet } * \text { Sosyo-ekonomik Düzey } \\
\text { (SED) }\end{array}$ & $\begin{array}{l}* \text { Sınıf *Bilgisayara Sahip } \\
\text { Olma }\end{array}$ \\
\hline 2 & $\begin{array}{l}\text { Güllü, Arslan, } \\
\text { Dündar \& } \\
\text { Murathan } \\
\text { (2012) }\end{array}$ & Makale & Belirtilmemiş & $\begin{array}{l}\text { İlkokul ve Ortaokul } \\
(4,5,6,7 \text { ve } 8 \text {. sınıf })\end{array}$ & $\begin{array}{l}525 \text { Öğrenci } \\
(\mathrm{K}: 298 \mathrm{E}: 227)\end{array}$ & $\begin{array}{c}* \text { Cinsiyet } * \text { Sınıf } * \text { Bilgisayara sahip } \\
\text { olma }\end{array}$ & $\begin{array}{l}\text { *Anne-babanın mesleği } \\
\text { *Ailenin aylık geliri } \\
\text { *Okul dışı boş zaman }\end{array}$ \\
\hline 3 & $\begin{array}{l}\text { Şahin \& Tuğrul } \\
\qquad(2012)\end{array}$ & Makale & Belirtilmemiş & $\begin{array}{l}\text { İlkokul ve Ortaokul } \\
\text { (4 ve } 5 \text {. sınıf) }\end{array}$ & $\begin{array}{l}372 \text { Öğrenci } \\
(K: 178 \mathrm{E}: 194)\end{array}$ & $\begin{array}{l}{ }^{*} \text { Cinsiyet *Bilgisayara sahip olma } \\
{ }^{*} \text { Anne eğitim düzeyi }\end{array}$ & $\begin{array}{c}* \text { Sınıf } * \text { Baba eğitim } \\
\text { düzeyi }\end{array}$ \\
\hline 4 & $\begin{array}{l}\text { Gökçearslan \& } \\
\text { Durakoğlu } \\
\text { (2014) }\end{array}$ & Makale & Belirtilmemiş & $\begin{array}{c}\text { Ortaokul } \\
(6,7 \text { ve } 8 \text {. sınıf })\end{array}$ & $\begin{array}{l}146 \text { Öğrenci } \\
(K: 84 \mathrm{E}: 62)\end{array}$ & $\begin{array}{l}{ }^{*} \text { Cinsiyet } * \text { Anne-babanın eğitim } \\
\text { düzeyi *Oyun oynama süresi }\end{array}$ & *Bilgisayara sahip olma \\
\hline 5 & $\begin{array}{l}\text { Taş, Eker \& Anlı } \\
\text { (2014) }\end{array}$ & Makale & Belirtilmemiş & Lise & $\begin{array}{l}268 \text { Öğrenci } \\
\text { (K:119 E:149) }\end{array}$ & $\begin{array}{l}\text { Hiçbir değişkenin etkisi } \\
\text { bulunmamıştır. }\end{array}$ & $\begin{array}{c}{ }^{*} \text { Cinsiyet } * \text { Sınıf } * \text { Okul } \\
\text { türü }\end{array}$ \\
\hline 6 & $\begin{array}{c}\text { Vollmer, } \\
\text { Randler, } \\
\text { Horzum \& Ayas } \\
\text { (2014) }\end{array}$ & Makale & Belirtilmemiş & Ortaokul - Lise & $\begin{array}{l}740 \text { öğrenci } \\
\text { (K: } 294 \\
\text { E: 446) }\end{array}$ & $\begin{array}{c}{ }^{*} \text { Cinsiyet }{ }^{*} \text { Yaş }{ }^{*} \text { Kişilik tipleri }{ }^{*} \text { Gece } \\
\text { insanı olma }\end{array}$ & Başka değişken yok \\
\hline 7 & $\begin{array}{c}\text { Aydın \& } \\
\text { Horzum (2015) }\end{array}$ & Makale & $\begin{array}{l}\text { Uygun } \\
\text { Örnekleme }\end{array}$ & Öğretmen & $\begin{array}{l}264 \text { Öğretmen } \\
\text { (K:164 E:100) }\end{array}$ & $\begin{array}{c}{ }^{*} \text { Cinsiyet } * \text { Duygusal denge } * \text { Günlük } \\
\text { oyun süresi }\end{array}$ & $\begin{array}{c}\text { *Yaş *Bilgisayar ve } \\
\text { internet sahibi olma } \\
\text { *Statü *Dışa dönüklük } \\
\text { *Yumuşak başlılık *Öz } \\
\text { denetim *Yeniliğe } \\
\text { açıklık }\end{array}$ \\
\hline 8 & Müezzin (2015) & Makale & $\begin{array}{c}\text { Ölçüt } \\
\text { Örnekleme }\end{array}$ & Lise & $\begin{array}{l}131 \text { Öğrenci } \\
(\mathrm{K}: 81 \mathrm{E}: 50)\end{array}$ & *Cinsiyet & Başka değişken yok \\
\hline 9 & $\begin{array}{l}\text { Çavuş, Ayhan \& } \\
\text { Tuncer (2016) }\end{array}$ & Makale & $\begin{array}{c}\text { Amaçlı } \\
\text { Örnekleme }\end{array}$ & Üniversite & $\begin{array}{l}435 \text { Öğrenci } \\
(K: 213 \mathrm{E}: 224)\end{array}$ & $\begin{array}{l}\text { *Cinsiyet *Ailenin ekonomik durumu } \\
\text { *Katılımcıların oyun oynama } \\
\text { alışkanlıkları *Oyun için yapılan } \\
\text { harcama *Oyun oynama süresi } \\
{ }^{*} \text { Anne-baba eğitim düzeyi }\end{array}$ & Başka değişken yok \\
\hline 10 & $\begin{array}{l}\text { Karaca } v d . \\
\quad(2016)\end{array}$ & Makale & Belirtilmemiş & Ortaokul & $\begin{array}{l}1019 \text { Öğrenci } \\
\text { (K:463 E:556) }\end{array}$ & $\begin{array}{c}{ }^{*} \text { Cinsiyet } * \text { Sınıf *Anne-baba eğitim } \\
\text { durumu *Bilgisayarda/internette } \\
\text { geçirilen süre *Evde internet } \\
\text { bağlantısı }\end{array}$ & Başka değişken yok \\
\hline 11 & $\begin{array}{c}\text { Toker } \& \\
\text { Baturay }(2016)\end{array}$ & Makale & Belirtilmemiş & Üniversite & $\begin{array}{l}159 \text { Öğrenci } \\
\text { (K: } 89 \mathrm{E}: 70)\end{array}$ & $\begin{array}{c}{ }^{*} \text { Cinsiyet } * \text { SES } * \text { Çevrimiçi ve } \\
\text { bilgisayar oyunları }\end{array}$ & $\begin{array}{l}\text { *Sigara içme *Anne } \\
\text { istihdam durumu } \\
\text { *Anne eğitim düzeyi }\end{array}$ \\
\hline 12 & $\begin{array}{l}\text { Ekinci, Yalçın, } \\
\text { Özer \& Kara } \\
\text { (2017) }\end{array}$ & Makale & Belirtilmemiş & Lise & $\begin{array}{l}931 \text { Öğrenci } \\
\text { (K:508 E:423) }\end{array}$ & ${ }^{*}$ Cinsiyet $*$ Spora katılım *Gelir düzeyi & *Konaklama yeri \\
\hline 13 & Gunuc (2017) & Makale & $\begin{array}{l}\text { Küme } \\
\text { Örnekleme }\end{array}$ & Lise & $\begin{array}{l}184 \text { öğrenci } \\
\text { (K: } \\
\text { Belirtilmemiş } \\
\text { E: } \\
\text { Belirtilmemiş) }\end{array}$ & *Akranlardaki bağımlılık düzeyi *Sınıf & ${ }^{*}$ Cinsiyet \\
\hline 14 & $\begin{array}{l}\text { Altun \& Atasoy } \\
\text { (2018) }\end{array}$ & Makale & $\begin{array}{c}\text { Amaçlı } \\
\text { Örnekleme }\end{array}$ & Ortaokul & $\begin{array}{l}1100 \text { öğrenci } \\
\text { (K: } 552 \text { E: 548) }\end{array}$ & Cinsiyet, yaş & Başka değişken yok \\
\hline 15 & $\begin{array}{l}\text { Eren \& Örsal } \\
\qquad(2018)\end{array}$ & Makale & $\begin{array}{l}\text { Örnekleme } \\
\text { Yapılmamış }\end{array}$ & $\begin{array}{l}\text { Illkokul } \\
\text { (4. sınıf) }\end{array}$ & $\begin{array}{l}205 \text { öğrenci } \\
\text { K:104 } \\
\text { E: } 101\end{array}$ & $\begin{array}{l}{ }^{*} \text { Cinsiyet *Kardeş sayısı *Anne ve } \\
\text { baba eğitim düzeyi *Günlük oyun } \\
\text { oynama süresi *Oyun oynama için } \\
\text { uykuyu reddetme düzeyi *Yalnızlık }\end{array}$ & Başka değişken yok \\
\hline
\end{tabular}




\begin{tabular}{|c|c|c|c|c|c|c|c|}
\hline No & Yayın başlığı & $\begin{array}{l}\text { Yayın } \\
\text { türü }\end{array}$ & $\begin{array}{l}\text { Örneklem } \\
\text { türü }\end{array}$ & Örneklem grubu & $\begin{array}{l}\text { Örneklem } \\
\text { boyutu }\end{array}$ & Anlamlı etkisi bulunan değişkenler & $\begin{array}{l}\text { Etkisi bulunmayan } \\
\text { değişkenler }\end{array}$ \\
\hline 16 & Göldağ (2018) & Makale & $\begin{array}{l}\text { Basit Seçkisiz } \\
\text { Örnekleme }\end{array}$ & Lise & $\begin{array}{l}517 \text { öğrenci } \\
\text { (K:266 E:251) }\end{array}$ & $\begin{array}{c}\text { *}^{*} \text { Cinsiyet, }{ }^{*} \text { Sabit internet } \\
\text { bağlantısına, mobil internet } \\
\text { bağlantısına, cep telefonuna, } \\
\text { bilgisayara sahip olma, }{ }^{*} \text { Anne eğitim } \\
\text { *Baba eğitim, *Aile gelir durumu } \\
\text { *Oyun oynama süreleri *Ailelerin } \\
\text { öğrencilerin oynadıkları oyunları } \\
\text { kontrol etme durumları }\end{array}$ & Başka değişken yok \\
\hline 17 & $\begin{array}{c}\text { Kircaburun, } \\
\text { Jonason \& } \\
\text { Griffiths (2018) }\end{array}$ & Makale & $\begin{array}{l}\text { Basit Seçkisiz } \\
\text { Örnekleme }\end{array}$ & $\begin{array}{c}\text { Çevrimiçi oyuncular } \\
\text { (Yaş ortalaması: } \\
\text { 20.82) }\end{array}$ & $\begin{array}{l}421 \text { çevrimiçi } \\
\text { oyuncu } \\
\text { (K: } 0 \\
\text { E: } 421 \text { ) }\end{array}$ & $\begin{array}{c}{ }^{*} \text { Kişilik özellikleri *Çevrimiçi oyun } \\
\text { motifleri * Oyun türü }\end{array}$ & $\begin{array}{l}\text { Tek başına kişilik } \\
\text { özellikleri direk etkiye } \\
\text { sahip değildir. }\end{array}$ \\
\hline 18 & $\begin{array}{l}\text { Kurt, Dogan, } \\
\text { Erdogmus \& } \\
\text { Emiroglu } \\
\text { (2018) }\end{array}$ & Makale & Belirtilmemiş & Ortaokul & $\begin{array}{c}300 \text { öğrenci } \\
\text { (K: } 166 \mathrm{E}: 134)\end{array}$ & $\begin{array}{l}\text { *Cinsiyet *Günlük oyun süresi } \\
\text { *Başkası ile oyun oynama }\end{array}$ & Başka değişken yok \\
\hline 19 & Erboy (2010) & $\begin{array}{l}\text { Yüksek } \\
\text { Lisans } \\
\text { tezi }\end{array}$ & $\begin{array}{l}\text { Küme } \\
\text { Örnekleme }\end{array}$ & $\begin{array}{l}\text { İlkokul ve Ortaokul } \\
\text { (4 ve } 5 . \text { sınıf) }\end{array}$ & $\begin{array}{l}638 \text { Öğrenci } \\
\text { (K:312 E:326) }\end{array}$ & $\begin{array}{c}{ }^{*} \text { Cinsiyet } * \text { Anne ve baba eğitim } \\
\text { düzeyi *Sınıf düzeyi *Okulun sosyo- } \\
\text { ekonomik düzeyi *Kişisel bilgisayara } \\
\text { sahip olma * Okula yabancılaşma } \\
\text { düzeyi }\end{array}$ & Başka değişken yok \\
\hline 20 & Çakılcı (2013) & $\begin{array}{l}\text { Yüksek } \\
\text { Lisans } \\
\text { tezi }\end{array}$ & $\begin{array}{c}\text { Kartopu } \\
\text { Örnekleme }\end{array}$ & $\begin{array}{l}\text { 18-40 yaş } \\
\text { aralığındaki } \\
\text { katılımcılar } \\
\text { (Bir yıldan uzun } \\
\text { süredir şiddet } \\
\text { içerikli çok } \\
\text { oyunculu çevrimiçi } \\
\text { video oyunu } \\
\text { oynayanlar) }\end{array}$ & $\begin{array}{c}205 \text { Kişi } \\
\text { (K:37 E:168) }\end{array}$ & *Yaş & ${ }^{*}$ Cinsiyet \\
\hline
\end{tabular}

*Cinsiyet *Günlük spora katılım 582 Öğrenci düzeyi *Sporcu lisansı olma durumu

21 Hazar (2014) Lisans tezi $22 \quad$ Bilgin (2015) $\quad \begin{gathered}\text { Yüksek } \\ \text { Lisans }\end{gathered}$ tezi

Tabakalı Örnekleme

Ortaokul

Öğrenci- Nicel:

Yüksek

24

Bekir (2018)

Lisans

tezi

Kurtbeyoğlu

Yüksek
Lisans

tezi

Yüksek

26

$\begin{array}{ccc}\text { Çakıcı (2018) } & \begin{array}{c}\text { Yüksek } \\ \text { Lisans } \\ \text { tezi }\end{array} & \begin{array}{c}\text { Basit Seçkisiz } \\ \text { Örnekleme }\end{array}\end{array}$

Ölçüt

Örnekleme

Kolay

Erişilebilir

Örnekleme
Ortaokul -

20 ebeveyn (K:326 E:256)

678 Öğrenci (K:308 E:370) 225

(K:91 E:131)

Veli - Nitel: 20

ve yılı *Haftalık spora katılım günü

*Akademik başarı *Aile gelir düzeyi

*Anne-baba eğitim düzeyi

*Cinsiyet *Sosyoekonomik düzey (SED)

*Sabit internet bağlantısına sahip olma *Dijital oyunları oynadıkları araçların sayısı *Anne- babalarının online cihazları günlük kullanma süresi *internet'te oyun oynama durumları *Günlük ortalama dijital oyun oynama süresi *Sınıf düzeyi *Yaş

380 Öğrenci (K:117 E:263)

822 Öğrenci (K:398 E:424)

*Cinsiyet *Oynanan oyun türü

*Cinsiyet *Oyun oynama süresi *Dijital oyun satın alma sıklığı * Oyun oynama nedeni *Ailenin aylık gelir düzeyi

300 Öğrenci (K:148 E:152)
Başka değişken yok

*Yaş *Sınıf düzeyi

*Bilgisayara sahip olma *internet bağlantısına sahip olma

*Cinsiyet * Oyun oynanan teknolojik cihazlar

*ikamet edilen yer

*Sınıf düzeyi *Oyun platformu *oyun türü

*Baba eğitim düzeyi

*Evde bilgisayar olması *Evde internet olması *Günlük internet kullanım

Tabloda da görüldüğü gibi çalışmalar özellikle 2017 ve 2018'de yoğunlaşmıştır. Pek çok farklı örneklem çeşidi kullanılmış olup, çalışmalardaki katılımcı sayıları da 150 ile 1000 arasında değişmektedir. Çalışmaların birçoğu tarama modelinde yapıldığı için büyük örneklemlerde çalışılmıştır. Ancak bağımlılık gibi hassas bir konuda beklenen amaçlı veya küme örneklem yöntemlerinin azlığı dikkat çekmektedir. Dahası çalışmaların önemli bir kısmında ise örneklem türü belirtilmemiştir. En fazla ilk, ortaokul ve lise öğrencileri örneklem olarak seçilmiştir yani çalışmaların büyük bir bölümünde veriler okullardan toplanmıştır. Çalışmaya nitel 
çalışmaların da eklenmesi amaçlanmış ancak makale seçim kriterlerine uyan ve bağımlılığın nedenlerini ortaya koyan nitel bir çalışmaya rastlanmamıştır. Araştırmada incelenen yayınların veri toplama araçlarına göre dağılımı Tablo 4'te sunulmuştur.

Tablo 4. İncelenen çalışmalardaki veri toplama araçları

\begin{tabular}{|c|c|c|c|}
\hline Adı & Detaylı Bilgiler & Ölçek Geliştiren-Uyarlayan & $\mathrm{N}$ \\
\hline \multirow{8}{*}{$\begin{array}{l}\text { Bağımlılık } \\
\text { Ölçekleri }\end{array}$} & Çocuklar İçin Bilgisayar Oyun Bağımlılığı Ölçeği & Horzum, Ayas ve Balta (2008) & 15 \\
\hline & 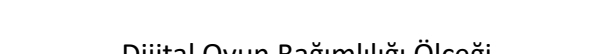 & Günüç ve Kayri (2010) & \\
\hline & Dijltal Uyun BagIm!migg Ulçegi & Lemmens, Valkenburg \& Peter (2012) & 4 \\
\hline & & Horzum Avasve Balta (2008) & \\
\hline & Ergenler İçin Bilgisayar Bağımlılığı Ölçeği & HOT Lum, Ayds ve Bdild ( 2000$)$ & 2 \\
\hline & & Ayas, Çakır ve Horzum (2011) & \\
\hline & Çevrimiçi Oyun Bağımlılığı Ölçeği & Kaya (2013) & 2 \\
\hline & $\begin{array}{l}\text { Araştırmacılar tarafından uyarlanan veya } \\
\text { geliştirilen ölçekler }\end{array}$ & & 3 \\
\hline \multirow{14}{*}{$\begin{array}{l}\text { Etki eden ya da } \\
\text { ilişkili faktörleri } \\
\text { inceleyen } \\
\text { ölçekler }\end{array}$} & İnternet Bağımlılık Ölçeği & Günüç (2009) & 2 \\
\hline & Sürekli Öfke ve Öfke Tarzı Ölçeği & Geliştiren Spielberger (1983) Uyarlayan Özer (1994) & 1 \\
\hline & Leahy Duygusal Şema Ölçeği & $\begin{array}{l}\text { Geliştiren Leahy (2002) Uyarlayan Yavuz, } \\
\text { Türkçapar, Demirel ve Karadere (2011) }\end{array}$ & 1 \\
\hline & Çok-Yönlü Eylemli Kişilik Ölçeği & $\begin{array}{l}\text { Geliştiren Coté (1997) Uyarlayan Atak, Kapçı ve Çok } \\
\text { (2013) }\end{array}$ & 1 \\
\hline & Çocuklar İçin Sosyal Anksiyete Ölçeği & $\begin{array}{l}\text { Demir, Eralp-Demir, Türksoy, Özmen ve Uysal } \\
\qquad(2000)\end{array}$ & 1 \\
\hline & Buss-Perry Saldırganlık Ölçeği & Madran (2012) & 1 \\
\hline & Sosyo-Ekonomik Düzey Ölçeği & Bacanlı (1997) & 1 \\
\hline & İletişim Becerileri Değerlendirme Ölçeği & Korkut (1996) & 1 \\
\hline & Öğrenci Yabancılaşma Ölçeği & Uzun-Yüksek (2006) & 1 \\
\hline & \multirow{2}{*}{ Kişilik Yapıları Ölçeği } & Gosling, Rentfrow ve Swann (2003) & \multirow{2}{*}{1} \\
\hline & & Uyarlayan: Günel (2010) & \\
\hline & UCLA Yalnızlık Ölıçeği & Demir (1989) & 1 \\
\hline & $\begin{array}{c}\text { Kötü Dörtlü Ölçeği (DTDD) (Negatif kişilik } \\
\text { özellikleri) }\end{array}$ & $\begin{array}{l}\text { Geliştiren: Özsoy, Rauthmann, Jonason ve Ardıç } \\
\qquad \text { (2017) }\end{array}$ & 1 \\
\hline & Sadistlik Dürtü Ölçeği (SSIS) & Geliştiren: O'Meara et al. (2011) & 1 \\
\hline TOPLAM & & & 37 \\
\hline Anket & Kişisel Bilgi Formu & - & 18 \\
\hline Görüşme & Yarı yapılandırıımış Görüşme Formu & - & 2 \\
\hline
\end{tabular}

Tablo 4'te görüldüğü gibi yapılan çalışmalarda ölçek, anket ve görüşme veri toplama araçları kullanılmıştır. Bu çalışmalarda genellikle mevcut olan ölçekler kullanılmış olup bazı çalışmalarda araştırmacılar tarafından geliştirilmiş ya da uyarlanmıştır. Ayrıca ölçek geliştiren-uyarlayan çalışmalar Ek-2'de sunulmuştur. Çalışmalarda etki eden faktörler için de yine mevcut ölçeklerden yararlanıırken çalışmaların büyük çoğunluğunda kişisel bilgi anketleri kullanılmıştır. Araştırma bulgularında da 
görüleceği gibi, demografik özellikler en fazla kullanılan değişkenlerdir. Bununla birlikte çalışmalarda nitel veri yok denecek kadar azdır.

Çalışmalarda öncelikle katılımcılar hakkında bilgi edinmek için kişisel bilgi formu sonrasında ise çalışmanın amacına uygun ölçek kullanılmıştır. Karma yöntem kullanılan bir çalışmada ise nicel veriler için ölçek, nitel veriler için görüşmeler yapılmıştır. Veri toplama araçları, sekiz çalışmada yüz yüze bizzat araştırmacı/lar tarafından, kalan iki çalışma ise çevrimiçi anket ya da okul yönetimi tarafından katılımcılar eliyle uygulanmıştır. Çalışmaların çoğunluğunda veri toplamanın kim tarafından nerede yapıldı̆̆ı belirtilmemiştir.

Tablo 5'te görüldüğü gibi yayınlanan tez ve makalelerde karşılaştırmalı ve ilişkisel analizler kullanılmıştır. Burada korelasyon analizinin fazla kullanılması, büyük örneklemlerle çalışılmasına rağmen parametrik olmayan testlerin kullanımı dikkat çekmektedir.

Tablo 5 İncelenen çalışmalarda kullanılan analiz türleri

\begin{tabular}{lcc}
\hline Analiz Türleri & Analiz Adları & N \\
\hline Karşılaştırma Analizleri & ANOVA & 11 \\
& Mann-whitney U testi & 9 \\
& Kruskal Wallis & 7 \\
& Korelasyon analizi & 6 \\
\hline Regresyon analizi & 10 \\
Kilişkisel Analizler & Ki-kare testi & 6 \\
& Kümeleme analizi & 2 \\
& Yapısal Eşitlik Modeli & 1 \\
& Sosyal Ağ Analizi & 1 \\
\hline
\end{tabular}

Araştırmada incelenen çalışmaların ifade ettikleri sınırlılıklar Tablo 6’da sunulmuştur.

Tablo 6 incelenen çalışmalarda ifade edilen sınırlılıklar

\begin{tabular}{lc}
\hline Çalışmaların Sınırlııkları & $\mathrm{N}$ \\
\hline Belli bir sınıf düzeyiyle çalışmaların yapılması & 6 \\
Veriler, kullanılan form ve ölçeklerdeki soruların doğası & 6 \\
Belli başı değişkenlerin (sosyo-ekonomik, sosyo-demografik özellikler gibi) kullanımı & 5 \\
Örneklem grubuna özgü sınırlılıklar & 5 \\
Belli bir okul türüyle çalışmaların yapılması & 3 \\
Sadece belirli sosyo-ekonomik gruba ait örneklemle çalışılması & 3 \\
Tüm katıımcıların tek bir ilden seçilmesi & 2 \\
Görüşmelerin sınırlı sayıda kişi ile yapılması & 2 \\
\hline
\end{tabular}

Tablo 6’da görüldüğü gibi çalışmaların sınırlılıklarında örneklem seçimi ile ilgili sorunlar göze çarpmaktadır. Öte yandan ölçeklerle ilgili sınırlılıklar da ifade edilen sorunlar arasındadır. Öte yandan özellikle makalelerde sınırlılıklar yeterli ölçüde ele alınmamıştır.

\section{Dijital Oyun Bağımlılığı Çalışmalarında Ele Alınan Değişkenler ve Bağımlılığa Etkilerine İlişkin Sonuçlar}

Araştırmada incelenen yayınlarda dijital oyun bağımlılığı çalışmalarında ele alınan değişkenler ile bu değişkenlerde etkili olan boyutlara ait açıklamalar Tablo 7'de sunulmuştur. 
Tablo 7 Dijital oyun bağımlılığı çalışmalarında ele alınan değişkenler ve etkililiklerine ilişkin bulgular

\begin{tabular}{|c|c|c|c|}
\hline Değişkenler & $\begin{array}{l}\text { Etkisi Bulunan } \\
\text { Çalışma Sayısı }\end{array}$ & $\begin{array}{c}\text { Etkisi } \\
\text { Bulunmayan } \\
\text { Çalışma Sayısı }\end{array}$ & Etkili olan boyutlarla ilgili açıklama \\
\hline Cinsiyet & 21 & 4 & Erkekler daha fazla bağımlılık düzeyine sahiptir \\
\hline Anne eğitim düzeyi & 9 & 1 & Anne eğitim düzeyinin artması bağımlılığı artırmıştır \\
\hline Günlük oyun oynama süresi & 8 & - & Oyun oynama süresi arttıkça bağımlılık artmıştır \\
\hline Sınıf düzeyi & 7 & 5 & Bağımlılık üst sınıf lehine artmıştır \\
\hline Baba eğitim düzeyi & 7 & 2 & Baba eğitim düzeyinin artması bağımlılı̆̆ artırmıştır \\
\hline Sosyoekonomik düzey (SED) & 5 & - & SED arttıkça bağımlılık artmıştır \\
\hline Bilgisayara sahip olma & 4 & 5 & $\begin{array}{l}\text { Etkisi yoktur. Sebebi, oyunların başka cihaz ve yerlerde de } \\
\text { oynanabilmesi }\end{array}$ \\
\hline Aile gelir düzeyi & 4 & 1 & Aile gelir düzeyi arttıkça bağımlılık artmıştır \\
\hline Yaş & 4 & 2 & Yaş arttıkça bağımlılık azalmıştır \\
\hline $\begin{array}{l}\text { Internet bağlantısına sahip } \\
\text { olma }\end{array}$ & 3 & 3 & $\begin{array}{l}\text { Fark yoktur. Bazı oyunların internet olmadan da oynanabilmesi } \\
\text { nedeniyle etkisi farklı çıkabilmektedir }\end{array}$ \\
\hline Oyun türü & 2 & 1 & PubG oyunu oynayanların bağımlılık düzeyleri daha yüksek olmuştur \\
\hline Dijital oyun satın alma sıklığı & 2 & - & Dijital oyun satın alma arttıkça bağımlılık artmıştır \\
\hline Kişilik yapısı boyutları & 2 & 2 & Fark yoktur. Nörotik bireylerin bağımlılık düzeyi daha yüksektir \\
\hline Haftalık spora katılım günü & 2 & - & Spora ayrılan süre arttıkça oyun bağımlılık puanları artmıştır \\
\hline $\begin{array}{l}\text { Dijital oyunları oynadıkları } \\
\text { araçlar }\end{array}$ & 1 & 2 & Kullanılan araçların etkisi yoktur \\
\hline Günlük internet kullanımı & 1 & 1 & $\begin{array}{l}\text { Fark yoktur. Sebebi, internetin yalnızca oyun oynamak için } \\
\text { kullanılmamasıdır }\end{array}$ \\
\hline Günlük spora katılım düzeyi & 1 & - & Spora katılmayanlar daha bağımlı bulunmuştur \\
\hline $\begin{array}{l}\text { Internet'te oyun oynama } \\
\text { durumları }\end{array}$ & 1 & - & $\% 60$ oranında etkisi bulunmuştur \\
\hline $\begin{array}{l}\text { Babalarının teknolojik cihazları } \\
\text { günlük kullanma süresi }\end{array}$ & 1 & - & Günlük 1-2 saat kullanma süreleri ile etkisi olmuştur \\
\hline $\begin{array}{l}\text { Annelerinin teknolojik } \\
\text { cihazları günlük kullanma } \\
\text { süresi }\end{array}$ & 1 & - & Günlük 1-2 saat kullanma süreleri ile etkisi olmuştur \\
\hline Oyun oynama nedenleri & 1 & - & $\begin{array}{c}\text { Meydan okuma, rakipleri yok etmek ve yenmek amacıyla oynayanların } \\
\text { bağımlılık düzeyi daha yüksek olmuştur }\end{array}$ \\
\hline $\begin{array}{l}\text { Sporcu lisansı olma durumu ve } \\
\text { yılı }\end{array}$ & 1 & - & Lisans yılı arttıkça bağımlılık düzeyi artmıştır \\
\hline Akademik başarı & 1 & - & Akademik başarı arttıkça bağımlııı puanları düşmüştür \\
\hline Okula yabancılaşma düzeyi & 1 & - & $\begin{array}{l}\text { Okula yabancılaşma düzeyi yüksek olan kişilerin bağımlılık düzeyi } \\
\text { yüksek olmuştur }\end{array}$ \\
\hline Sabah-gece insanı olma & 1 & - & $\begin{array}{c}\text { Gece insanı (gece kendini daha enerjik hissetme) olma durumu } \\
\text { bağımlılığı artırmıştır }\end{array}$ \\
\hline Kişilik boyutları & 1 & - & $\begin{array}{c}\text { Big5 kişilik yapılarından duygusal denge oyun bağımlılı̆̆ı ile ters } \\
\text { orantılıdır. }\end{array}$ \\
\hline Akranlardaki bağımlılık düzeyi & 1 & - & Yakın arkadaşı olmayan bireyler daha bağımlı olmuştur \\
\hline Kardeş Sayısı & 1 & - & Kardeş sayısı arttıkça bağımlılık artmıştır \\
\hline Yalnızlık & 1 & - & Oyun bağımlıı̆̆ı çok olanların yalnızlığı artmıştır \\
\hline Okul türü & - & 1 & Okulun türüne göre etkisi olmamıştır \\
\hline Statü & - & 3 & Statünün etkisi olmamıştır \\
\hline İkamet edilen yer & - & 2 & $\begin{array}{c}\text { Dijital araçlara her yerde ulaşılabilirlik mümkün olduğundan etkisi } \\
\text { olmamıştır }\end{array}$ \\
\hline Okul dışı boş zaman & - & 1 & Okul dışı boş zaman anlamlı düzeyde farklılaşmamıştır \\
\hline TOPLAM & 96 & 36 & - \\
\hline
\end{tabular}

Tablo 7'de görüldüğü gibi incelenen çalışmalarda toplam 33 farklı değişkene yer verilmiştir. Genel olarak cinsiyet açısından erkeklerin bağımlıığa yatkın olduğu, anne babanın eğitim düzeyi, sosyoekonomik düzey, dijital araçlara ve imkanlara sahip olma ve oyun oynama düzeyi arttıkça bağımlılığın arttığı görülmektedir. Sınıf düzeyi arttıkça bağımlılık artmasına rağmen yaşın ele alındığı çalışmalarda elde edilen sonuçlar tam tersidir. Akademik başarı, spor yapma, duygusal denge düzeyi gibi unsurlar 
bağımlılıkla ters orantılı iken, yalnızlık, yabancılaşma, gece insanı olma, nevrotik bozukluk gibi psikososyal unsurlar doğru orantılıdır.

\section{TARTIŞMA VE SONUÇ}

Bu çalışma daha nitelikli dijital oyun bağımlılığı çalışmaları geliştirebilmek, orijinal araştırma fikirleri ortaya koymak ve araştırmacılara bir yol haritası sunmak amacıyla yürütülmüş olup çalışmalardaki metodolojik unsurlarla ele alınan değişkenler detaylı biçimde incelenmiştir. Dijital oyun bağımlılığı ile ilgili alanyazın incelendiğinde, metodolojik olarak pek çok dikkat edilmesi gereken unsur ile bağımlılıkla ilişkili olabilecek yeni faktörlerin ele alınması gerekliliği ortaya çıkmaktadır. Çalışmalarda benzer bazı değişkenlerin bağımlılık üzerindeki etkilerine değinilmiş olması artık literatürü bu konuda doygun hale getirirken, kullanılan metodolojilerdeki birtakım eksiklikler bu çalışmaların tekrar ele alınması gerekliliğini de ortaya koymaktadır.

Dijital oyun bağımlılığı çalışmalarının çoğunluğu okullarda, ilkokul, ortaokul ve lise düzeyindeki belli örneklem gruplarında toplanmıştır. Her ne kadar yöntemlerde amaçlı olarak ifade edilse de bunun seçilen yaş grubu ile sınırlı kaldığı, katılımcıların seçiminde herhangi bir kriterin uygulanmadığı anlaşılmaktadır. Benzer şekilde yurt dışında dijital oyun bağımlılı̆ı ile ilgili 58 ampirik çalışmanın incelendiği sistematik incelemede de örneklemin çoğu kez araştırmacının kendisinin belirlediği temsil ediciliği düşük örneklemlerle çalışıldığı tespit edilmiştir (Kuss \& Griffiths, 2012). Örneklem sayıları çalışmalarda oldukça yeterli olmasına rağmen, bu tür çalışmalarda örneklemin büyüklüğünden çok doğru örneklemin seçilmiş olması önemlidir. Çünkü özellikle ilişkisel çalışmalarda örneklem büyüdükçe değişkenler arası anlamlı ilişkiler bulunması ihtimali artmaktadır. iliş̧kisel analizler aynı zamanda hiçbir zaman kesin olarak bir nedeni ortaya koyamaz ve her zaman bir başka değişkenin etken olma ihtimali vardır. Asamoah (2014) bu durumu şöyle örneklemektedir; “...istatistiksel analizin, bireylerin ortalama televizyon izleme saatleri ile şiddete meyilleri arasında "bireyler ne kadar çok televizyon izlerse, şiddet eylemleri yapma olasılıkları o kadar artar" güçlü ve istikrarlı bir şeklinde korelasyon olduğunu varsayalım. Bu sonuçlar kendi başına araştırmacılara televizyon izlemenin insanları şiddet eylemlerine daha meyilli olup olmadığını açıklamaz, belki de üçüncü faktör -zayıf sosyal beceriler veya işsizlik- gibi hesaba katılmayan, şiddetin ve televizyon izlemenin artmasının gerçek sebebi olabilir" (p. 49). Şiddet içerikli video oyunlarının saldırgan davranışlar üzerindeki ilişkisini ortaya koyan bir meta-analiz çalışmasında, şiddet içerikli video oyunu oynamanın bireylerde kişilik yapısını etkilediğini göstermekte ancak bağımlılıkla olan ilişkisi düşük çıkabilmektedir (Anderson \& Carnagey, 2004). Bu tür bağımlılık çalışmalarında çok düşük olsa da ilişki olabileceği fakat gerçek bağımlılık düzeylerini ortaya çıkarmada zayıf kaldıkları söylenebilir. Yani bağımlılık skorları çok küçük olsa da bir ilişki bulunabilmekte, bu nedenle korelasyonel çalışmalar gerçek bağımlılığı ortaya koymada zayıf kalabilmektedir (Anderson \& Carnagey, 2004). Ayrıca incelenen çalışmalarda sadece ilişkisel bir analiz yapılması pratik öneriler getirmede de yeterli olmayacaktır, çünkü iki taraflı bir etkileşim söz konusudur, yani etken bilinmemektedir ve etkenleri bilinmeyen bir olgu için öneriler getirmek de zor olacaktır. Dolayısı ile bağımlılık çalışmalarında ilişkisel analizler yapılırken gerçekten doğru bir teori üzerine şekillendirilmesi gerekmektedir.

İncelenen çalışmalarda çoğunlukla bağımlılığı ölçmek için mevcut dijital oyun bağımlılığı ölçekleri kullanılmıştır, dolayısı ile sadece bu konudaki ampirik çalışmaların hemen hemen hepsi nicel çalışmalardır. Bağımsız değişkenlere ait veriler için ise çoğunlukla yine mevcut bazı ölçeklerle kişisel bilgi formu kullanıldığı görülmektedir. Katılımcıların kişisel veya demografik bilgilerini öğrenmek için çoğunlukla anketler kullanılmıştır. Analiz dosyasında yer alan unsurlardan biri olmasına rağmen veriyi toplama şekli hakkında incelenen çalışmalarda yeterli bilgi verilmemiş olması sebebiyle bulgularda yer almamıştır. Ancak örneklemden anlaşıldığı kadarıyla veriler genellikle okullarda ve sınıflarda toplanmıştır. Oysa, bağımlılık çalışmalarında veriyi araştırmacının toplaması, veriler toplanırken katılımcıların yanında olan kişiler, verilerin online ya da ortamda araştırmacı yokken örneğin okuldaki öğretmen tarafından toplanması sonucu farklı şekillerde etkileyebilmektedir. Araştırmacının kendisinin verileri toplaması veri kaybı yaşanmaması ve katılımcılara anında cevap verilebilmesi için önemli olsa da özellikle çocuk yaştaki bireylerden bağımlılık gibi hassas bir konuda metodolojik olarak çok daha dikkatli olunması gerekmektedir (Griesler, Kandel, Schaffran, Hu, \& Davies, 2008). Bağımlılık çalışmalarında sosyal beğenilirlik sorunu yani öğrencinin gerçekte olanı değil, kendisinden başkalarının beklediği cevapları vermesi problemi sıklıkla yaşanmaktadır (Ogan, Karakuş, \& Kurşun, 2013). Avrupa çapında 25 binden fazla 9-16 yaş grubu çocuktan toplanan verilerde, odada bir başka kişinin bulunmasının (akran, ebeveyn veya araştırmacı) hassas sorulara verilen cevaplarda daha fazla sosyal beğenilirlik unsuru oluştuğu ve yaş grubu küçüldükçe bunun arttığı saptanmıştır (Ogan ve diğ., 2013). Öte yandan verinin online ortamda toplanması da hem doğru bilgiye hem de doğru örnekleme ulaşmada farklı problemler doğurabilir. Dolayısı ile bağımlılık gibi hassas bir konudaki çalışmalarda, örneklemin doğru seçilmesi, sadece kişisel raporlama şeklinde alınan verilerin yerine daha doğru, sosyal beğenilirlik sorunu yaşanmadığından emin olacak şekilde çalışmaların yürütülmesi gerekmektedir. Bu tür çalışmalarda bilişsel görüşme adı verilen ve çocuğun soruları cevaplarken gözlemlenerek sorulara ilişkin tepkilerinin analiz edildiği ve böylece veri toplama araçlarının daha uygun hale getirildiği ön çalışmalar yapılması da önerilebilir.

Metodolojik olarak yapılan incelemelerde özellikle makalelerde sınırlılıklardan yeterince bahsedilmediği görülmektedir. Bu tür çalışmalarda sonuçların genellenebilmesi ve ileriki çalışmalar için rehberlik etmesi için sınırlılıkların ifade edilmesi oldukça önemlidir. İncelenen çalışmalarda tüm tezlerde bu kısma değinilmiş ve genel olarak örneklem, ele alınan değişkenler ve ölçme araçları ile ilgili sınırıııklar ifade edilmiştir. Aslında pek çok çalışma, bağımlıı̆̆ın ele alınan değişkenlerle ilişkili olamayabileceğini, kültürel, sosyal ve kişisel birçok farklı etmenin mevcudiyetini ve örneklemin yeterince temsil ediciliği olmayabileceğini kabul etmektedir (Donati, Chiesi, Ammannato, \& Primi, 2015; Griffiths ve diğ., 2004; Jeong, Kim, \& Lee, 2017). Bu sorunların çözümü ile yapılacak yeni çalışmalar dijital oyun bağımlılığı literatürüne daha anlamlı katkılar sağlayacaktır. 
Çalışmalarda ele alınan değişkenler ve sonuçlar incelendiğinde, cinsiyet, bilgisayara sahip olma, internet bağlantısına sahip olma gibi demografik değişkenler için genellikle karşılaştırma testlerinin; sınıf düzeyi, anne-baba eğitim durumu, sporcu lisans yılı, spor yapılan gün sayısı, akademik başarı, katılımcıların yaşları gibi değişkenler için ise ilişkisel analizlerin kullanıldığı görülmüştür. Bu değişkenler dijital bağımlıık çalışmalarında sıklıkla ele alınan unsurları oluşturmaktadır. Cinsiyet açısından erkeklerin kızlara göre daha fazla dijital oyun bağımlısı oldukları belirlenmiştir. Alan yazında, erkeklerin bilgisayar oyunlarına kızlardan daha çok ilgili olup zaman ayırdıkları ve oyun bağımlılık düzeyinin kızlardan daha yüksek olduğu ve bilgisayar oyunlarının etkilerine daha çok maruz kaldıkları saptanmış ve araştırmadaki bulgularla paralellik göstermiştir (Erboy, 2010; Horzum, 2011; Gökçearslan \& Durakoğlu, 2014; Çavuş, Ayhan \& Tuncer, 2016; Kurtbeyoğlu, 2018). Ailelerin gelir düzeyi değişkenine göre, gelir seviyesi arttıkça bağımlılık düzeyinin arttığı saptanmıştır (Horzum, 2011; Çavuş, Ayhan \& Tuncer, 2016). Sosyoekonomik düzeyi yüksek olan bireylerin oyun bağımlılık düzeyinin yüksek olduğu belirtilmiştir ve bu durum genellikle bilgisayar ya da diğer dijital araçlara sahip olma ve aktif kullanma ile açıklanmaktadır. Anne ve babanın öğrenim düzeyi açısından oyun bağımlılığı düzeylerinin anlamlı biçimde farklılaştığı, öğrenim düzeyi arttıkça çocuklarının oyun bağımlılı̆ı düzeyinin de arttığı sonucuna ulaşımıştır. Bazı çalışmalarda ise babaların eğitim durumlarının dijital oyun bağımlılığı üzerinde anlamlı bir etkisi bulunmamıştır (Şahin \& Tuğrul, 2012; Çakıcı, 2018). Anne ve babanın eğitim durumu yükseldikçe meslek sahibi olma ihtimalinin yükselmesi, bu nedenle ebeveyn gözetiminden uzak olmaları bunun bir nedeni olarak görülmektedir. Bilgisayar oyun bağımlılı̆ı düzeylerinin evlerinde bilgisayar olma durumuna göre bakıldığında, çoğu çalışmada farklılaşmadığı saptanmıştır (Horzum, 2011; Gökçearslan \& Durakoğlu, 2014; Bilgin, 2015). Katılımcıların özellikle erkeklerin istediği zaman internet kafe ya da PlayStation salonları gibi ortamlara gidebilmesi ve istediği oyunu oynamak için elinde alternatif mobil cihazların bulunması nedeniyle günümüzde evde bilgisayar olma durumunun bir fark oluşturması beklenmemektedir. Akademik başarının lisans yıl sayısı ile negatif ilişkili olduğu, lisans yılı arttıkça akademik başarının düştüğü ve akademik başarı arttıkça bağımlılık puanlarının düştüğü tespit edilmiştir. Ayrıca sporcu lisansı olanlarla olmayanların bağımlılık puanları arasındaki farkın erkek katılımcılardan kaynaklandığı anlaşımaktadır. Bu durum da lisans sahibi olmanın kadınlarda bağımlılık puanlarını etkilemediği erkeklerde ise olumsuz etkilediği sonucuna ulaşılmıştır. Bu nedenle bağımlılık çalışmalarında farklı hobiler edinmenin, aktif olmanın ve sosyalleşmenin iyi birer çözüm yolu olduğu vurgulanmaktadır. Çalışmalarda nadiren psikososyal özellikler ile oyunlara özgü değişkenler ele alınmış olup değişkenlerin hemen hemen hepsi oyuncuların gündelik alışkanlıkları, oyun oynama alışkanlıkları, demografik unsurlar gibi tamamen kişisel unsurlara dayalıdır. Bunun nedeni çalışmalarda yeterince ön çalışma ile teorik bir alt yapı oluşturmanın, ele alınabilecek farklı faktörleri araştırmanın hem zaman hem de deneyim gerektirmesi olabilir. Oysa sadece demografik bulguların ele alındığı çalışmalarla bağımlılık uzmanlarının ya da bağımlının çevresindekilerin önlem almalarını sağlayabilecek öneriler getirilmesi zordur. Oysa oyun bağımlılı̆ı çalışmalarında oyunların farklı özelliklerinin, kişilerin psikolojik durumlarının (Griffiths ve diğ., 2004), farklı farklı oyun türlerinin oynanmasının (Donati ve diğ., 2015), yalnızlık, depresyon ve agresiflik gibi psikososyal problemlerin (Jeong ve diğ., 2017) bağımlılık üzerinde etkileri olduğuna dair çalışmalar mevcuttur. Dolayısı ile yeni çalışmalarda seçilen değişkenlerin gerçekten manipüle edilebilecek, değiştirilebilecek veya iyileştirilebilecek unsurlardan seçilmesi daha pratik çözüm önerileri sunulmasını sağlayacaktır.

Çalışmalarda dijital oyun bağımlılığı ile ilişkili olan değişkenler incelendiğinde teorik olarak yeterince çerçevesinin çizilmediği ifade edilebilir. Örneğin, çalışmalarda günlük oyun oynama süresi ile bağımlık arasındaki ilişkiye bakılması aslında teorik olarak uygun değildir. Çünkü bağımlıık aşırı kullanım, dürtü etkisiyle yapılan, kontrol edilemeyen psikolojik ve fiziksel yıkıcı davranışlarla ifade edilmektedir (Mendelson \& Mello, 1986). Oyun oynama süresi zaten dijital oyun bağımlılığının göstergelerinden biridir, dolayısı ile aralarında anlamlı fark oluşmaması mümkün değildir. Bir olgu ile içinde barındırdığı unsur arasında ilişkisel analizlerin yapııması anlamlı olmamaktadır. Ayrıca dijital oyun bağımlılığı çalışmalarında "aşırı oyun oynama davranışı" ile "bağımlılı̆ın" da benzer kavramlar olarak kullanıldığı, aslında aşırı oyun oynama kavramının kişinin yaşamında negatif sonuçlar doğurmayan eğlenceli oyun oynama olduğu, ancak çoğu bağımlılık çalışmasının aslında "aşırı kullanımı" ele aldığı öne sürülmektedir (Grüsser, Thalemann, \& Griffiths, 2006; Daria Joanna Kuss \& Griffiths, 2012). Bazı ölçekler incelendiğinde kendini unutma, gerçek yaşamdan uzaklaşma yoksun kaldığında öfkeli olma, önemli aktiviteleri erteleme ya da unutma gibi bağımlılığın en riskli davranışlarını içermediği görülmektedir (Kaya, 2013). Dolayısı ile bu konuda çalışma yapacak araştırmacıların çalışmalarında gerçekte tam olarak neyi ölçtüğünü iyi belirlemeleri gerekmektedir. Öte yandan öğrencilere özellikle küçük yaştakilere ebeveyn eğitim düzeyi, sosyoekonomik durum, ya da ebeveyn ile ilgili farklı sorular sorulması da incelenmesi gereken bir konudur. Çünkü çocuklar genellikle bu konularda da sosyal beğenilirlik davranışı göstermesi ya da bu konuda fikrinin olmaması muhtemeldir. Dolayısı ile bu tür verilerin bizzat ilgili kişilerden alınması daha doğru sonuçlar verecektir.

Sonuç olarak bu çalışma ülkemizde yapılan dijital oyun bağımlılığı çalışmalarında dikkat edilmesi gereken unsurlar üzerinde öneriler getirmiştir. Çalışma belirli yıllar arasında Türkiye'de yapılmış ve belirli veri tabanlarında taranan çalışmalar ile sınırlıdır. Çalışmanın hazırlanma aşamasında 2018 yıına kadar yapılmış çalışmalar ele alınmıştır. Çalışmanın değerlendirme sürecinde ise bu çalışmanın tartışmalarında bulunan bazı önerilere uygun yeni çalışmalar ortaya koyulmuştur. Özellikle çocuklarda sosyalleşme ile ilgili farklı problemleri (Barut, 2019; Nurullayeva, 2019; Taş \& Güneş, 2019), oyun oynama motivasyonları (Hazar, 2019) gibi farklı faktörlerin dijital oyun bağımlılığına olan etkilerinin incelendiği çalışmalar mevcuttur. Ancak hala bağımlığı derinlemesine anlamayı sağlayacak nitel yöntemlerle desteklenmiş, metodolojileri açık ve uygun çalışmalara ihtiyaç vardır. Ayrıca, daha fazla faktörün ortaya çıkması, metodolojik olarak farklılıkların ortaya koyulması için yeni çalışmalarda yerli ve yabancı çalışmalar arası karşılaştırmalar yapılması, özellikle metodolojik olarak dikkat edilmesi gereken unsurlara odaklanılması gerekmektedir. Son olarak, Web of Science'da 2010-2018 yılları arasında Türkiye'de yürütülmüş çalışma sayısı 62 iken, sadece 2019 - 2020 yıllarında

| Kastamonu Eğitim Dergisi, 2020, Vol. 28, No. 4| 
41 makale yayınlanmıştır. Bu gözle görülür biçimde artan ampirik çalışmaların yeni literatür çalışmaları ile dijital oyun bağımlıı̆̆ının farklı boyutlarının ele alınması da araştırmacılara önerilebilir.

\section{KAYNAKÇA}

Altun, M. \& Atasoy, M. (2018). Investgation Of Digital Game Addicton Of Children Between 9-11 Age Groups: Kırşehir Sample. International Journal of Eurasia Social Sciences, 9(33), 1740-1757.

Anderson, C. A., \& Carnagey, N. L. (2004). Violent evil and the general aggression model. The social psychology of good and evil, 168-192.

Anderson, C. A., Carnagey, N. L., Flanagan, M., Benjamin, A. J., Eubanks, J., \& Valentine, J. C. (2004). Violent video games: Specific effects of violent content on aggressive thoughts and behavior. Advances in experimental social psychology, 36, 200-251.

Asamoah, M. K. (2014). Re-examination of the limitations associated with correlational research. Journal of Educational Research and Reviews, 2(4), 45-52.

Aslan, A. (2016). Türkiye'de Çocukların Güvenli Internet Kullanımında 2010-2015 Yılları Arasındaki Değişimler ve Uygulamaların Yansımaları (Doktora tezi). Atatürk Üniversitesi, Erzurum.

Barut, B. (2019). Ergenlerde dijital oyun bağımlılık düzeyi ile algılanan sosyal destek ve duygu düzenle me arasındaki ilişkinin incelenmesi (Yüksek lisans tezi). Hasan Kalyoncu Üniversitesi, Gaziantep.

Bhagat, S., Jeong, E. J., \& Kim, D. J. (2020). The Role of Individuals' Need for Online Social Interactions and Interpersonal Incompetence in Digital Game Addiction. International Journal of Human-Computer Interaction, 36(5), 449-463.

Carnagey, N. \& Anderson, C. (2004). Violent Video Game Exposure and Aggression : A Literature Review. Minerva Psichiatrica, 45(1), 118.

Chou, T. \& Ting, C. (2003). The role of flow experience in cyber-game addiction. CyberPsychology \& Behavior, 6(6), 663-675.

Cohen, L., Manion, L. \& Morrison, K. (2007). Research methods in education (6th ed.). New York, NY: Routledge.

Denyer, D., \& Tranfield, D. (2009). Producing a systematic review. Buchanan, D. and Bryman, A. (Eds), The Sage Handbook of Organizational Research Methods (pp. 671-689), Sage Publications, Londra.

Donati, M. A., Chiesi, F., Ammannato, G., \& Primi, C. (2015). Versatility and addiction in gaming: The number of video-game genres played is associated with pathological gaming in male adolescents. Cyberpsychology, Behavior, and Social Networking, 18(2), 129-132.

Ferguson, C. J. (2007). The good, the bad and the ugly: A meta-analytic review of positive and negative effects of violent video games. Psychiatric quarterly, 78(4), 309-316.

Gough, D., Oliver, S. \& Thomas, J. (2012). An introduction to systematic reviews. London England: Sage.

Greitemeyer, T. (2018). The spreading impact of playing violent video games on aggression. Computers in human behavior, 80, $216-219$.

Griesler, P. C., Kandel, D. B., Schaffran, C., Hu, M.-C., \& Davies, M. (2008). Adolescents' inconsistency in self-reported smoking: A comparison of reports in school and in household settings. Public Opinion Quarterly, 72(2), 260-290.

Griffiths, M. \& Meredith, A. (2009). Videogame addiction and its treatment. Journal of Contemporary Psychothe rapy. On the Cutting Edge of Modern Developments in Psychotherapy,39(4), 247-253. http://dx.doi.org/10.1007/s10879-009-9118-4 adresinden alındı

Griffiths, M. D., Davies, M. N., \& Chappell, D. (2004). Demographic factors and playing variables in online computer gaming. CyberPsychology \& behavior, 7(4), 479-487.

Grüsser, S. M., Thalemann, R., \& Griffiths, M. D. (2006). Excessive computer game playing: Evidence for addiction and aggression?. Cyberpsychology \& behavior, 10(2), 290-292.

Guba, E. L., \& Lincoln, Y. (1994). Competing paradigms in qualitative research. Handbook of cualitative research. California: Sage, $105-117$.

Gündüz, A. (2015). Internet Güvenliği Üzerine 2000-2014 Yılları Arasındaki Çalışmaların Bir İ̧̧erik Analizi: Riskler, Risklere Etki Eden Faktörler ve Metodolojik Yönelimler (Yüksek lisans tezi). Atatürk Üniversitesi, Erzurum.

Hazar, Z. (2019). An Analysis of the Relationship between Digital Game Playing Motivation and Digital Game Addiction among Children. Asian Journal of Education and Training, 5(1), 31-38.

Henson, R. K., Hull, D. M., \& Williams, C. S. (2010). Methodology in our education research culture: Toward a stronger collective quantitative proficiency. Educational Researcher, 39(3), 229-240.

Ilgaz, H. (2015). Adaptation of game addiction scale for adolescents into Turkish. Elementary Education Online, 14(3), 874-884.

Irmak, A. \& Erdoğan, S. (2016). Ergen ve genç erişkinlerde dijital oyun bağımlılığ: Güncel bir bakış. Türk Psikiyatri Dergisi, 27(2), 128137.

İnal, Y. \& Çağılttay, K. (2005). Illköğretim Öğrencilerinin Bilgisayar Oyunu Oynama Alışkanlıkları Ve Oyun Tercihlerini Etkileyen Faktörler. Eğitimde Yeni Yönelimler II. Eğitimde Oyun Sempozyumu. Ankara Özel Tevfik Fikret Okulları.

Jeong, E. J., Kim, D. J., \& Lee, D. M. (2017). Why do some people become addicted to digital games more easily? A study of digital game addiction from a psychosocial health perspective. International Journal of Human-Computer Interaction, 33(3), 199-214.

Kaya, A. B. (2013). Çevrimiçi oyun bağımlılığı ölçeğinin geliştirilmesi: Geçerlik ve güvenirlik çalışması (Yüksek lisans tezi). Gaziosmanpaşa Üniversitesi, Tokat. https://tez.yok.gov.tr/UlusalTezMerkezi adresinden edinilmiştir.

Khan, K. S., Kunz, R., Kleijnen, J., \& Antes, G. (2003). Five steps to conducting a systematic review. Journal of the royal society of medicine, 96(3), 118-121. 
Kim, E. J., Namkoong, K., Ku, T., \& Kim, S. J. (2008). The relationship between online game addiction and aggression, self-control and narcissistic personality traits. European psychiatry, 23(3), 212-218.

Kim, H., Sefcik, J. S., \& Bradway, C. (2017). Characteristics of qualitative descriptive studies: A systematic review. Research in nursing \& health, 40(1), 23-42.

Kneer, J., \& Glock, S. (2013). Escaping in digital games: The relationship between playing motives and addictive tendencies in males. Computers in Human Behavior, 29(4), 1415-1420.

Krefting, L. (1991). Rigor in qualitative research: the assessment of trustworthiness. The American Journal of Occupational Therapy, 45(3), 214222.

Kuss, D. J., \& Griffiths, M. D. (2012). Internet gaming addiction: A systematic review of empirical research. International Journal of Mental Health and Addiction, 10(2), 278-296.

Kuss, D. J., Louws, J., \& Wiers, R. W. (2012). Online gaming addiction? Motives predict addictive play behavior in massively multiplayer online role-playing games. Cyberpsychology, Behavior, and Social Networking, 15(9), 480-485.

Lemmens, J. S., \& Hendriks, S. J. (2016). Addictive online games: Examining the relationship between game genres and Internet gaming disorder. Cyberpsychology, Behavior, and Social Networking, 19(4), 270-276.

Lemmens, J. S., Valkenburg, P. M., \& Peter, J. (2009). Development and validation of a game addiction scale for adolescents. Media psychology, 12(1), 77-95.

López, X., Valenzuela, J., Nussbaum, M., \& Tsai, C. C. (2015). Some recommendations for the reporting of quantitative studies, Computers \& Education, 91 (2015), pp. 106-110

Martinez-Garza, M. M., Clark, D. B., Killingsworth, S. S., \& Adams, D. M. (2016). Beyond Fun: Pintrich, Motivation to Learn, and Games for Learning Handbook of Research on Gaming Trends in P-12 Education (pp. 1-32): IGI Global.

Mendelson, J., \& Mello, N. (1986). Chelsea House; New York: 1986. The addictive personality.[Google Scholar].

Nurullayeva, N. (2019). Ortaokul Öğrencilerinde Dijital Oyun Bağimliliği i̇le Aleksitimi Ve Üstbilişsel Sorun Arasindaki İlişkinin İncelenmesi (Yüksek lisans tezi). İstanbul Aydın Üniversitesi, İstanbul.

Ogan, C., Karakuş, T., \& Kurşun, E. (2013). Methodological issues in a survey of children's online risk-taking and other behaviours in Europe. Journal of Children and Media, 7(1), 133-150.

Ögel, K. (2012). Internet Bağımlılığı-Internetin Psikolojisini Anlamak ve Bağımlılıkla Başa Çıkmak. İstanbul:Iş Bankası Kültür.

Peters, M. D., Godfrey, C. M., Khalil, H., Mclnerney, P., Parker, D., \& Soares, C. B. (2015). Guidance for conducting systema tic scoping reviews. International journal of evidence-based healthcare, 13(3), 141-146.

Scholar Google. (2020). "Dijital Oyun Bağımlığı" Arama Sonuçları, 2020, from https://scholar.google.com.tr/scholar?q=dijital+oyun+ba\%C4\%9F\%C4\%B1ml\%C4\%B1I\%C4\%B1\%C4\%9F\%C4\%B1+\&hl=tr\&as_sdt= 0\%2C5\&as_ylo=2010\&as_yhi=2018

Taş, I., \& Güneş, Z. (2019). 8-12 yaş arası çocuklarda bilgisayar oyun bağımlılığı, aleksitimi, sosyal anksiyete, yaş ve cinsiyetin incelenmesi. Klinik Psikiyatri, 22, 83-92.

Toker, S., \& Baturay, M. H. (2016). Antecedents and consequences of game addiction. Computers in Human Behavior, 55, 668-679.

Web of Science. (2020). "Game addiction" anahtar kelimesi ile arama sonuçları, from https://apps.webofknowledge.com/ WOS_GeneralSearch_input.do?product=WOS\&search_mode=GeneralSearch\&SID=F4TPSKMfCag3gBwyzBJ\&preferencesSaved=

Weber, R., Ritterfeld, U., \& Kostygina, A. (2006). Aggression and hostility as effects of playing violent games. Playing video gamesMotives, responses, and consequences, 347-361.

Weinstein, A. M. (2010). Computer and Video Game Addiction: A Comparison between Game Users and Non-Game Users. The American Journal of Drug and Alcohol Abuse, 36(5), 268-276. doi: 10.3109/00952990.2010.491879

Yee, N. (2006). Motivations for play in online games. CyberPsychology \& behavior, 9(6), 772-775.

Yıldırım, A. \& Şimşek, H. (2011). Sosyal bilimlerde nitel araştırma yöntemleri. Ankara: Seçkin.

Yüksel, H. (2006). Online Ölüm Tarikatı. Aktüel, 27, 22-26.

\section{EK-1: Incelenen Çalışmaların Kaynakçası}

1. Horzum, M. B. (2011). İlköğretim öğrencilerinin bilgisayar oyunu bağımlılık düzeylerinin çeşitli değişkenlere göre incelenmesi. Eğitim ve Bilim, 36(159), 56-68.

2. Güllü, M., Arslan, C., Dündar, A. \& Murathan, F. (2012). Illköğretim öğrencilerinin bilgisayar oyun bağımlılıklarının incelenmesi. Adıyaman Üniversitesi Sosyal Bilimler Enstitüsü Dergisi, 5(9), 89-100.

3. Şahin, C. \& Tuğrul, V. M. (2012). İlköğretim öğrencilerinin bilgisayar oyunu bağımlılık düzeylerinin incelenmesi. Zeitschrift für die Welt der Türken/Journal of World of Turks, 4(3), 115-130.

4. Gökçearslan, Ş. \& Durakoğlu, A. (2014). Ortaokul öğrencilerinin bilgisayar oyunu bağımlılık düzeylerinin çeşitli değişkenlere göre incelenmesi. Dicle Üniversitesi Ziya Gökalp Eğitim Fakültesi Dergisi, 23(14), 419-435.

5. Taş, I., Eker, H. \& Anlı, G. (2014). Ortaöğretim Öğrencilerinin İnternet ve Oyun Bağımlılık Düzeylerinin İncelenmesi. Online Journal of Technology Addiction\&Cyberbullying, 1(2), 37-57.

6. Vollmer, C., Randler, C., Horzum, M. B., \& Ayas, T. (2014). Computer game addiction in adolescents and its relationship to chronotype and personality. Sage Open, 4(1), 2158244013518054. 
7. Aydın, F.\& Horzum, M. B. (2015). Öğretmenlerin Bilgisayar Oyun Bağımlılık Düzeylerini Yordayan Değişkenlerin İncelenmesi. Online Journal Of Technology Addiction \& Cyberbullying, 2(1), 52-66.

8. Müezzin, E. (2015). An Investigation of High School Students' Online Game Addiction with Respect to Gender. Turkish Online Journal of Educational Technology(1), 55-60. ERIC veritabanından alındı. (EJ 1124399).

9. Çavuş, S., Ayhan, B. \& Tuncer, M. (2016). Bilgisayar oyunları ve bağımlılık: Üniversite öğrencileri üzerine bir alan araştırması. iletişim Kuram ve Araştırma Dergisi, (43).

10. Karaca, S., Gok, C., Kalay, E., Başbuğ, M., Hekim, M., Onan, N. ve Barlas, G.U. (2016). Ortaokul Öğrencilerinde Bilgisayar Oyun Bağımlılığı ve Sosyal Anksiyetenin İncelenmesi. Clinical And Experimental Health Sciences, 6(1), 14-19. doi:10.5152/clinexphealthsci.2016.053.

11. Toker, S., Baturay, M.H. (2016). Antecedents and consequences of game addiction. Computers in Human Behavior, 55, 668-679.

12. Ekinci, N. E., Yalçın, I.., Özer, Ö.\& Kara, T. (2017). An Investigation of the Digital Game Addiction between High School Students. Online Submission, 14(4), 4989-4994. ERIC veritabanından alındı. (ED585257).

13. Gunuc, S. (2017). Peer Influence in Internet and Digital Game Addicted Adolescents: Is Internet / Digital Game Addiction Contagious? International Journal of High Risk Behaviors and Addictio, 6(2), doi: 10.5812/ijhrba.33681.

14. Altun, M., Atasoy, M. (2018). Investıgatıon Of Dıgıtal Game Addıctıon Of Chıldren Between 9-11 Age Groups: Kırşehir Sample. International Journal of Eurasia Social Sciences, 9(33), 1740-1757.

15. Eren, H. K., \& Örsal, Ö. (2018). Computer game addiction and loneliness in children. Iranian journal of public health, 47(10), 1504-1510.

16. Göldağ, B. (2018). Lise Öğrencilerinin Dijital Oyun Bağımlılık Düzeylerinin Demografik Özelliklerine Göre İncelenmesi. YYü Eğitim Fakültesi Dergisi, 15(1),1287-1315.

17. Kircaburun, K., Jonason, P. K., \& Griffiths, M. D. (2018). The Dark Tetrad traits and problematic online gaming: The mediating role of online gaming motives and moderating role of game types. Personality and Individual Differences, 135, 298-303.

18. Kurt, A. A., Dogan, E., Erdogmus, Y. K., \& Emiroglu, B. G. (2018). Examining Computer Gaming Addiction in Terms of Different Variables. World Journal on Educational Technology: Current Issues, 10(1), 29-40. Retrieved from ERIC database. (EJ1170394)

19. Erboy, E. (2010). Illköğretim 4. ve 5. Sınıf Öğrencilerinin Bilgisayar Oyun Bağımlılığına Etki Eden Faktörler (Yüksek lisans tezi). Adnan Menderes Üniversitesi, Aydın.

20. Çakılcı, E. F. (2013). Çok Oyunculu Çevrimiçi Video Oyunu Oynayan Bireylerde Video Oyunu Bağımlılığı ve Saldırganlık (Yüksek lisans tezi). Başkent Üniversitesi, Ankara.

21. Hazar, K. (2014). Lise Öğrencilerinde Internet ve Bilgisayar Oyun Bağımlıı̆ının Spora Katılım Düzeyi ve Bazı Değişkenlerle ilişkisinin Araştırılması (Yüksek lisans tezi). Niğde Üniversitesi, Niğde.

22. Bilgin, H. C. (2015). Ortaokul Öğrencilerinin Bilgisayar Oyun Bağımlılık Düzeyleri ile iletişsim Becerileri Arasındaki Ilişki (Yüksek lisans tezi). Pamukkale Üniversitesi, Denizli.

23. Yiğit, E. (2017). Çocukların Dijital Oyun Bağımlıı̆ında Ailelerin Bazı Değişkenler Açısından Incelenmesi (Yüksek lisans tezi). Yüzüncü Yıl Üniversitesi, Van.

24. Bekir, S. (2018). Üniversite Öğrencilerinde Çevrimiçi Oyun Bağımlıl̆ğı Düzeyinin Duygusal Şemalar, Eylemli Kişilik ve Bazı Değişkenler Açısından Incelenmesi (Yüksek lisans tezi). Sakarya Üniversitesi, Sakarya.

25. Kurtbeyoğlu, Ş. (2018). Ortaokul Öğrencilerinin Demografik Özelliklerinin Oyun Bağımlıı̆ı ile ilişkisi (Yüksek lisans tezi). Bahçeşehir Üniversitesi, İstanbul.

26. Çakıcı, G. (2018). Ergenlerde Dijital Oyun Bağımlılığı ve Öfkeyi Ifade Etme Biçimleri Arasındaki Ilişkinin İncelenmesi (Yüksek lisans tezi). Haliç Üniversitesi, İstanbul.

\section{EK-2: Dijital Oyunlarla IIIgili Geliştirilen - Uyarlanan Ölçekler için Kaynakça}

1. Atak, H., Kapçi, E. G. ve Çok, F. (2013). Çok-Yönlü Eylemli Kişilik Ölçeği'nin Türkçe formunun değerlendirilmesi. Düşünen Adam, 26(1), 36-45.

2. Ayas, T., Çakır, Ö. ve Horzum, M. B. (2011). Ergenler İçin Bilgisayar Bağımlıı̆ı̆ı Ölçeği. Kastamonu Eğitim Dergisi, 19(2), $439-448$.

3. Bacanlı, H. (1997). Sosyal ilişkilerde benlik kendini ayarlamanın psikolojisi, Milli Eğitim Bakanlığı Yayınları, Eğitim Dizisi, 14, ̇̇stanbul: Milli Eğitim Basımevi.

4. Demir A. (1989). Validity and reliability of the UCLA Loneliness Scale. J Psychol, 7(23), 14-18.

5. Demir, T., Eralp-Demir, D., Türksoy, N., Özmen, E. ve Uysal, Ö. (2000). Çocuklar İçin Sosyal Anksiyete Ölçeğinin geçerlilik ve güvenilirliği. Düşünen Adam Dergisi, 13(1), 42-48.

6. Günel, Ö.D. (2010). İşletmelerde Yıldırma Olgusu ve Yıldırma Mağdurlarının Kişilik Özelliklerine İlişkin Bir Araştırma. Dokuz Eylül Üniversitesi Sosyal Bilimler Enstitüsü Dergisi. 12(3), 37-65.

7. Günüç, S. (2009). Internet Bağımlıık Ölçeğinin geliştirilmesi ve bazı demografik değiş̧kenler ile internet bağımlıı̆̆ı arasındaki ilişkilerin incelenmesi. (Yüksek Lisans tezi). Yüzüncü Yıl Üniversitesi, Van.

8. Günüç, S., ve Kayri, M. (2010). Türkiye'de internet bağımlılık profili ve İnternet Bağımlılık Ölçeğinin geliştirilmesi: Geçerlik-güvenirlik çalışması. Hacettepe Üniversitesi Eğitim Fakültesi Dergisi, 39, 220-232.

9. Horzum, M. B., Ayas, T. ve Balta, Ö. (2008). Çocuklar İçin Bilgisayar Oyun Bağımlılığı Ölçeği. Türk Psikolojik Danışma ve Rehberlik Dergisi, 3(30), 76-88. 
10. Kaya, A. B. (2013). Çevrimiçi oyun bağımlılığı ölçeğinin geliştirilmesi: Geçerlik ve güvenirlik çalışması. (Yüksek lisans tezi). Gaziosmanpaşa Üniversitesi, Tokat.

11. Korkut, F. (1996). İletişim Becerilerini Değerlendirme Ölçeğinin Geliştirilmesi: Güvenirlik ve geçerlik çalışmaları. Psikolojik Danışma ve Rehberlik Dergisi, 2(7), 18-23.

12. Lemmens, J.S., Valkenburg, P.M. \& Peter, J. (2012). Develop-Ment And Validation Of A Game Addiction Scale For Adolescents. Media Psychology, 12(1), 77-95. doi.org/10.1080/15213260802669458.

13. Madran, H. A. D. (2012). Buss-Perry saldırganlık Ölçeği'nin Türkçe formunun geçerlik ve güvenirlik çalışması. Türk Psikoloji Dergisi, 24(2), 1-6.

14. O'Meara, A., Davies, J., \& Hammond, S. (2011). The psychometric properties and utility of the Short Sadistic Impulse Scale (SSIS). Psychological Assessment, 23, 523-531.

15. Özer, A. K. (1994). Sürekli Öfke ve Öfke İfade Tarzı Ölçekleri Ön Çalışması. Türk Psikoloji Dergisi, 9(31), 26-35.

16. Özsoy, E., Rauthmann, J F., Jonason, P K., Ardiç, K. (2017). Reliability and validity of the Turkish versions of Dark Triad Dirty Dozen (DTDD-T), Short Dark Triad (SD3-T), and Single Item Narcissism Scale (SINS-T). Personality And Individual Differences, 117(15),11-14. DOI: 10.1016/j.paid.2017.05.019.

17. Uzun-Yüksek, Ö. (2006). İlköğretim 5. sınıf öğrencilerinin okula yabancılaşma düzeylerine etki eden sosyo-demografik değişkenlerin belirlenmesi (Yayımlanmamış yüksek lisans tezi). Çukurova Üniversitesi, Adana

18. Yavuz, F. K., Türkçapar, M. H., Demirel, B. \& Karadere, E. (2011). Üniversite Öğrencileri ve Çalışanları Örnekleminde Leahy Duygusal Şema Ölçeği'nin Türkçe uyarlaması, geçerlilik ve güvenilirliği. Düşünen Adam Psikiyatri ve Nörolojik Bilimler Dergisi, $24,273-282$. 